\title{
APPALACHIAN GEOLOGY
}

Synthesizing information through a dinosaur toy:

An integrative assignment that is scalable for a variety of learners 


\section{GLY 1842-Dinosaurs: Then \& Now}

\section{Pedagogical/Philosophical Course Goals}

- ....describe the history of dinosaur knowledge, from prescientific mythological explanations to the current synthesis

- ...articulate an understanding and appreciation of fundamental principles of geological and biological sciences as applied to dinosaur paleontology.

- ...acquire a basic understanding of paleontological and evolutionary principles.

- ...demonstrate proficiency in acquiring, interpreting, and disseminating dinosaur knowledge.

- ...incorporate scientific, especially geological perspective into the educational experience at ASU. 


\section{Paleontology as a Gateway Science}

\section{Pragmatic Course Goals}

- Get 250-300 credit hours/offering w/out lab.

- Maintain standards w/out reading 80+ papers.

- Encourage students to take GLY courses for science requirement.

- Pick up a few majors and minors.

- Make the administration happy, especially those in charge of general education.

- Force a few more folks to face the " $e$ " word, deep time, and other scientific concepts. 


\section{GLY 1842-Nuts-and-bolts}

- Geology course, but non-science theme

- Counts toward general education, GLY minor

- 3 credit hours, no lab

- either MWF 50 minutes; TR 75 min.

- Fall 2015, TR, $n=57$; Fall 2016 MWF $n=78$

- Use ASULearn (Moodle) course software

- Textbook is Holtz \& Rey (2007)

- Cheap, but "free" (rental)

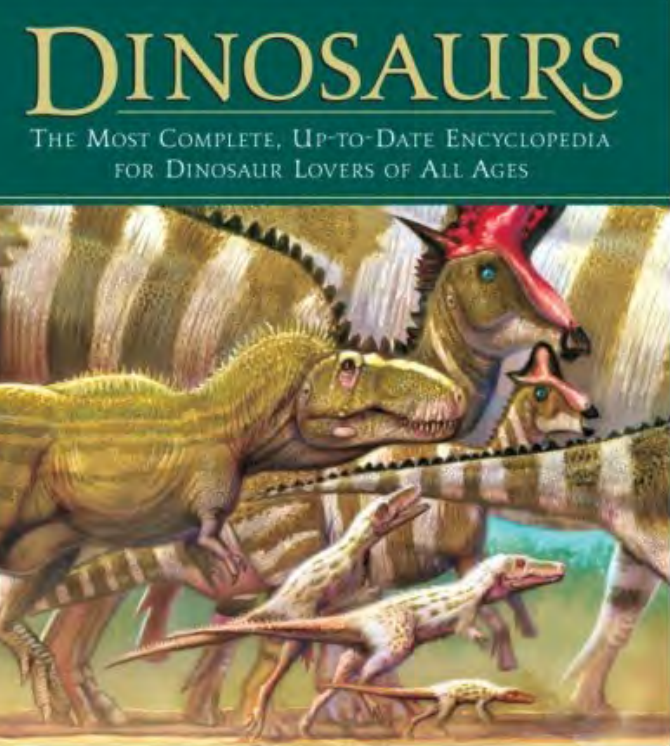




\section{GLY 1842-Nuts-and-bolts}

- Course grade based on

- $8 \%$ Participation (mostly clickers)

- $5 \%$ Weekly (more or less) "prequizzes" on ASULearn

- $8 \%$ ASULearn exam 1 (date info)*

- $8 \%$ ASULearn exam 2 (date info)*

- $8 \%$ ASULearn exam 3 (date info)*

- $8 \%$ ASULearn exam 4 (date info)*

- $9 \%$ In-class exam (date info)*

- $11 \%$ In-class exam 2 (date info) ${ }^{*}$

- $20 \%$ Dinosaur projects (See below; due dates TBA)

- $15 \%$ Final exam (date info)

- Total: $100 \%$

- *Exam dates are immutable-see http://www.registrar.appstate.edu/calendar/fallexampolicy.html 
Instructions: Choose (obtain) a non-avian dinosaur toy of your choosing, albeit with the following caveats:

(1) It is of a recognizable dinosaur*;

(2) It is a children's toy or a scale model of an entire dinosaur (not just a skull); and

(3) It has been mass-produced (your review will benefit other purchasers)
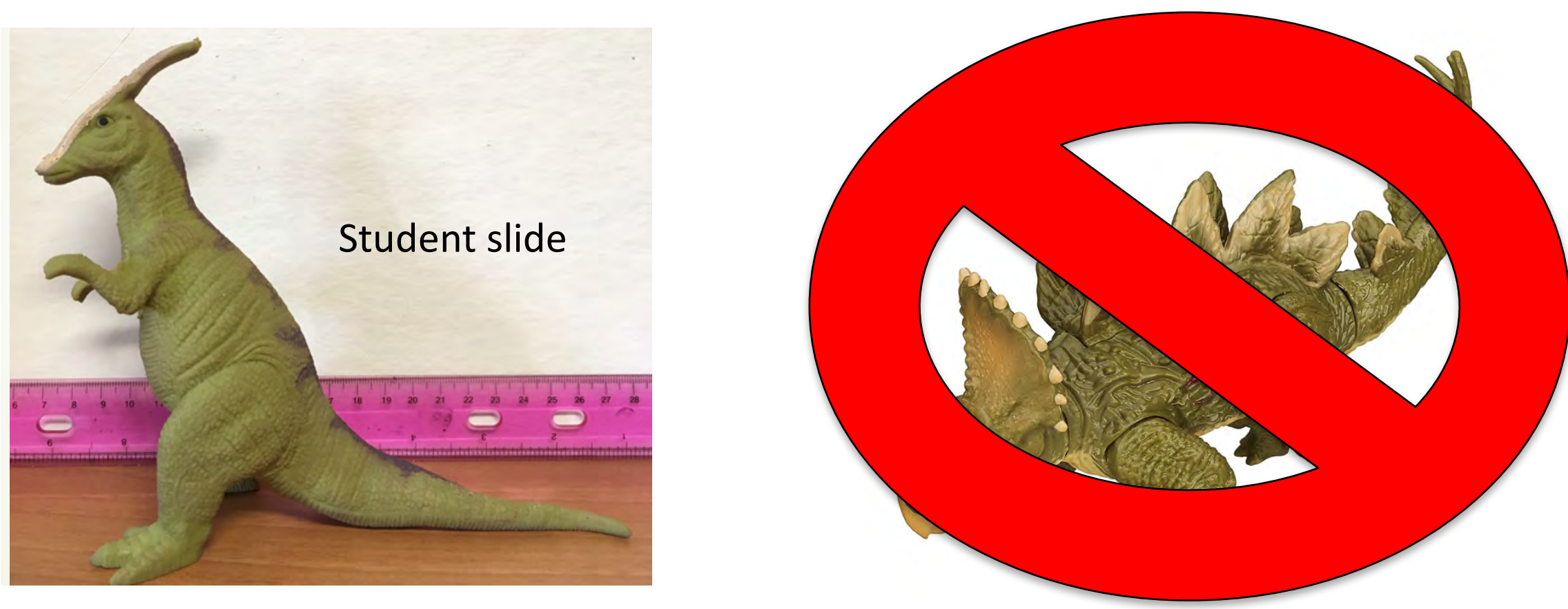

*I might accept a non-dinosaurian toy (e.g., a pterosaur), but any non-dinosaur has to be cleared with me first. 
Document and review the toy. This includes labeled pictures of the toy in at least three views, an indication of its size and scale, its classification (Linnaean and cladistic), and an understanding of the "Who, what, when, where, why/how" of the dinosaur. Provide some indication of the strengths and weaknesses of the toy.

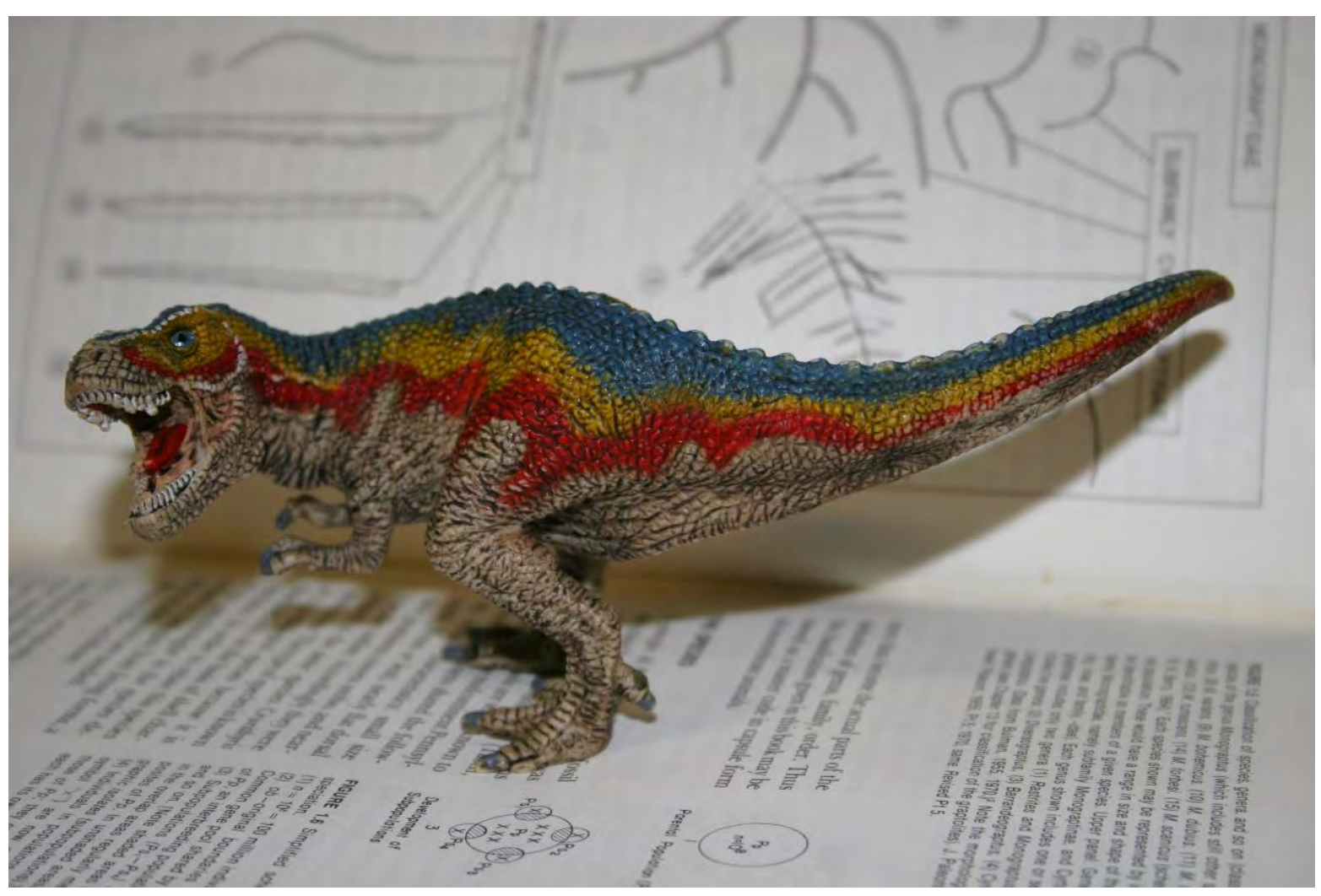

Student slide 


\section{Assignment web page}

\section{Dinosaur Toy Review}

This is where information regarding the "dinosaur toy review" assignment will be posted.

+ Final Dinosaur Toy Upload Site $\angle$

This is the place to upload your final dinosaur toy review project. Do not be late. Late submissions will be penalized enough that you were better off turning it in on time but incomplete.

Please upload your first dinosaur toy ppt here. This should include a title slide with your name and the name of the dinosaur as well as a slide(s) with a few pictures. Please see "ABHDinoToySelectionMockup" for details.

Please save your file as LastnameDinosaurToy, where "Last Name" is your last name, and dinosaur is the subject of your project. Thus, if ABH did Tricerotops, it would be HeckertTriceratopsToy 


\section{GLY 1842-Toy choice mock-up}

- IU Field Camp Philosophy: Practice everything

- Dinosaur toy selection is a brief assignment

- "Low stakes"

- Text in green is an aside for this presentation

- "ABH" in corner means my slide

- "student slide" means an actual submitted slide (used w/permission). 


\section{"Mock-up"/template}

- This is ABH's "template" for the assignment

- This is a minimum-I encourage you to be creative and expand on it and make it yours, I just wanted to provide examples

- So feel free to pick your background colors, fonts, artwork, etc.

- Slides with "Don't" on them mean "Don't do this" as in they are bad examples. 


\section{Some Do's and Don'ts}

- DO italicize your genus name (e.g.,

Coelophysis)

- And species, too! E.g., C. bauri

- DON'T italicize any other taxonomic name (Theropoda, Dinosauria)

- DO document your sources

- DO use Google Scholar® (scholar.google.com)

- DON'T just rely on the Wikipedia

- DON'T include slides like this one and the previous 


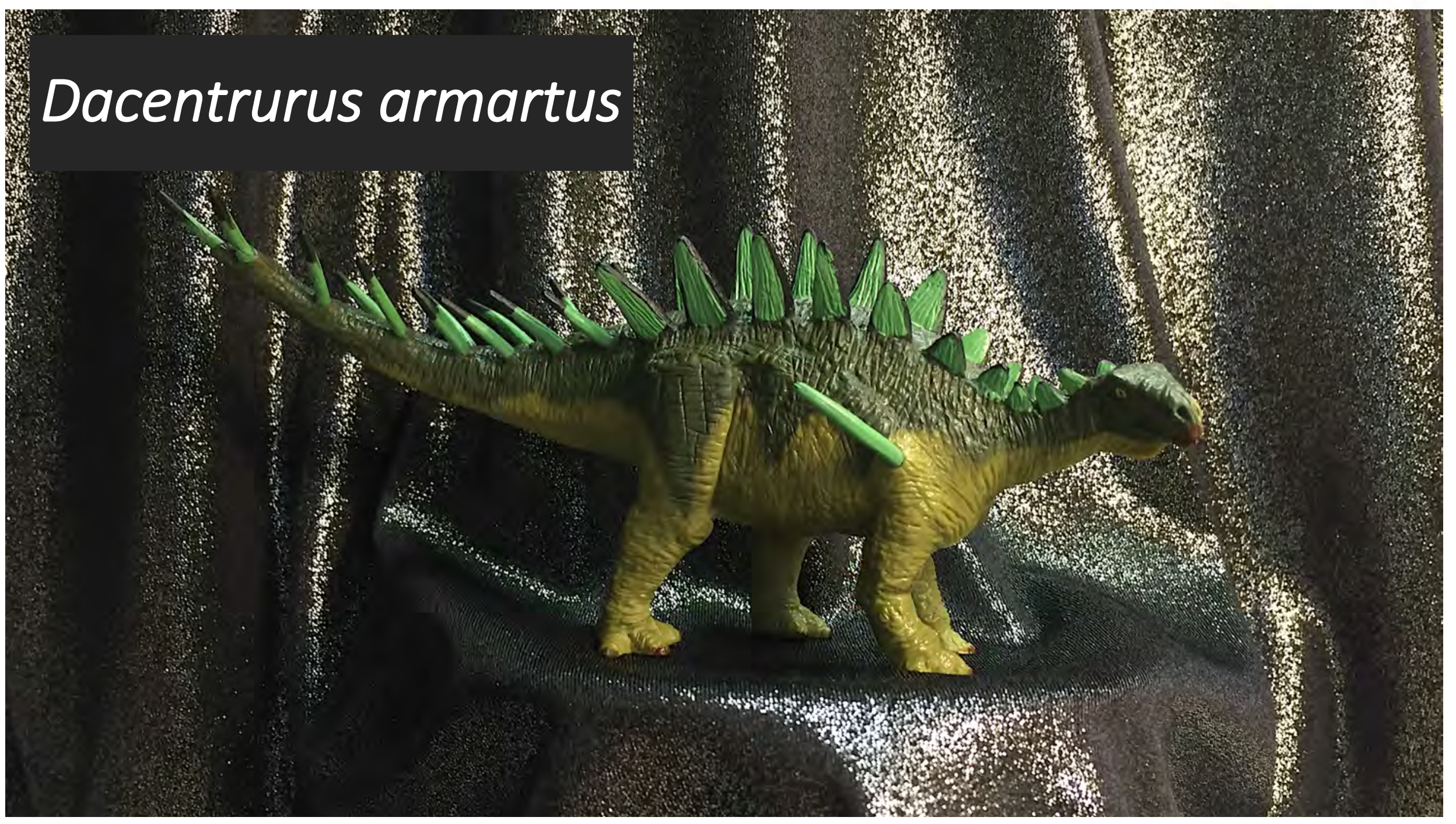

Student slide 



\section{Coelophysis in dorsal view}

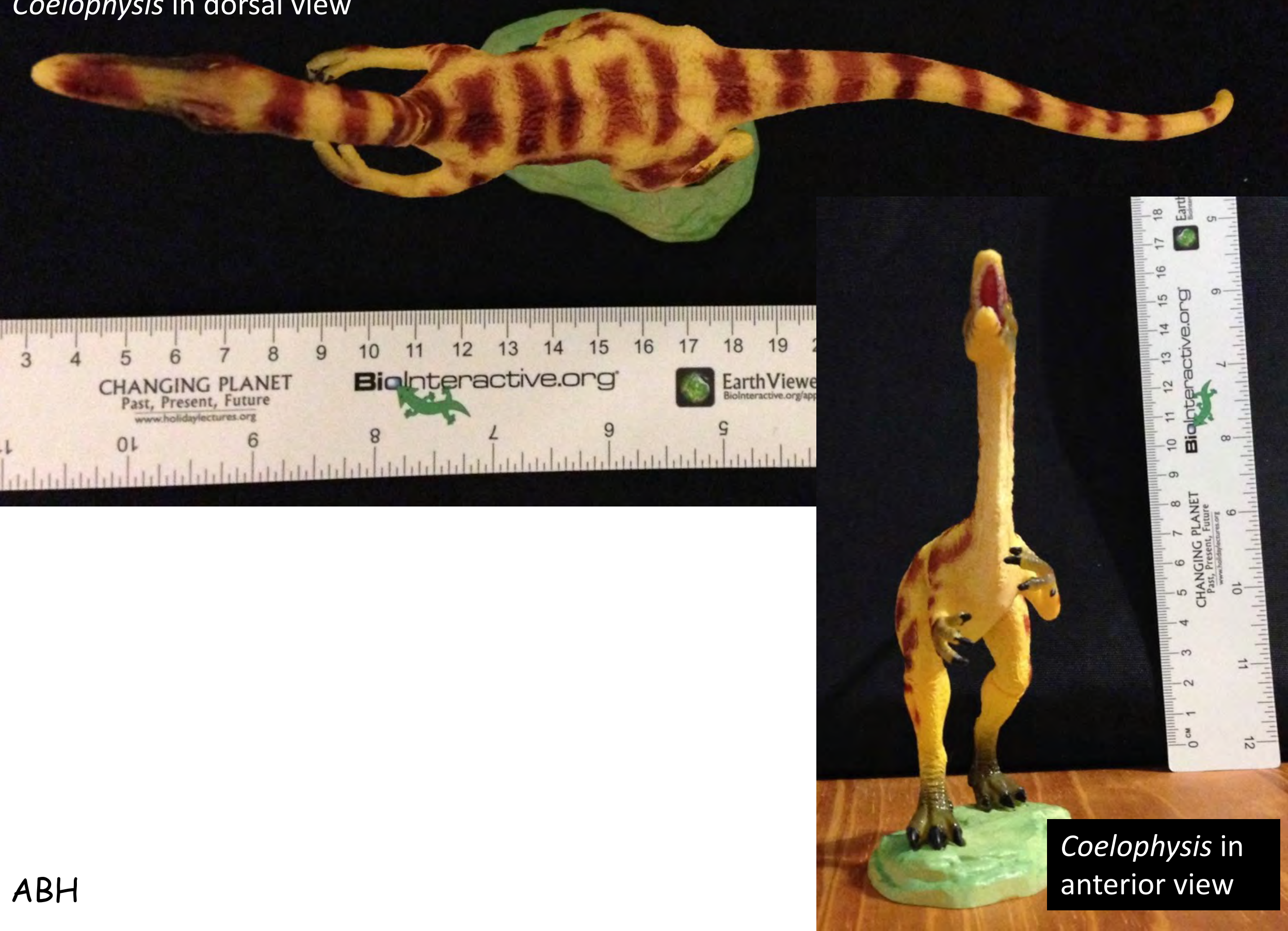




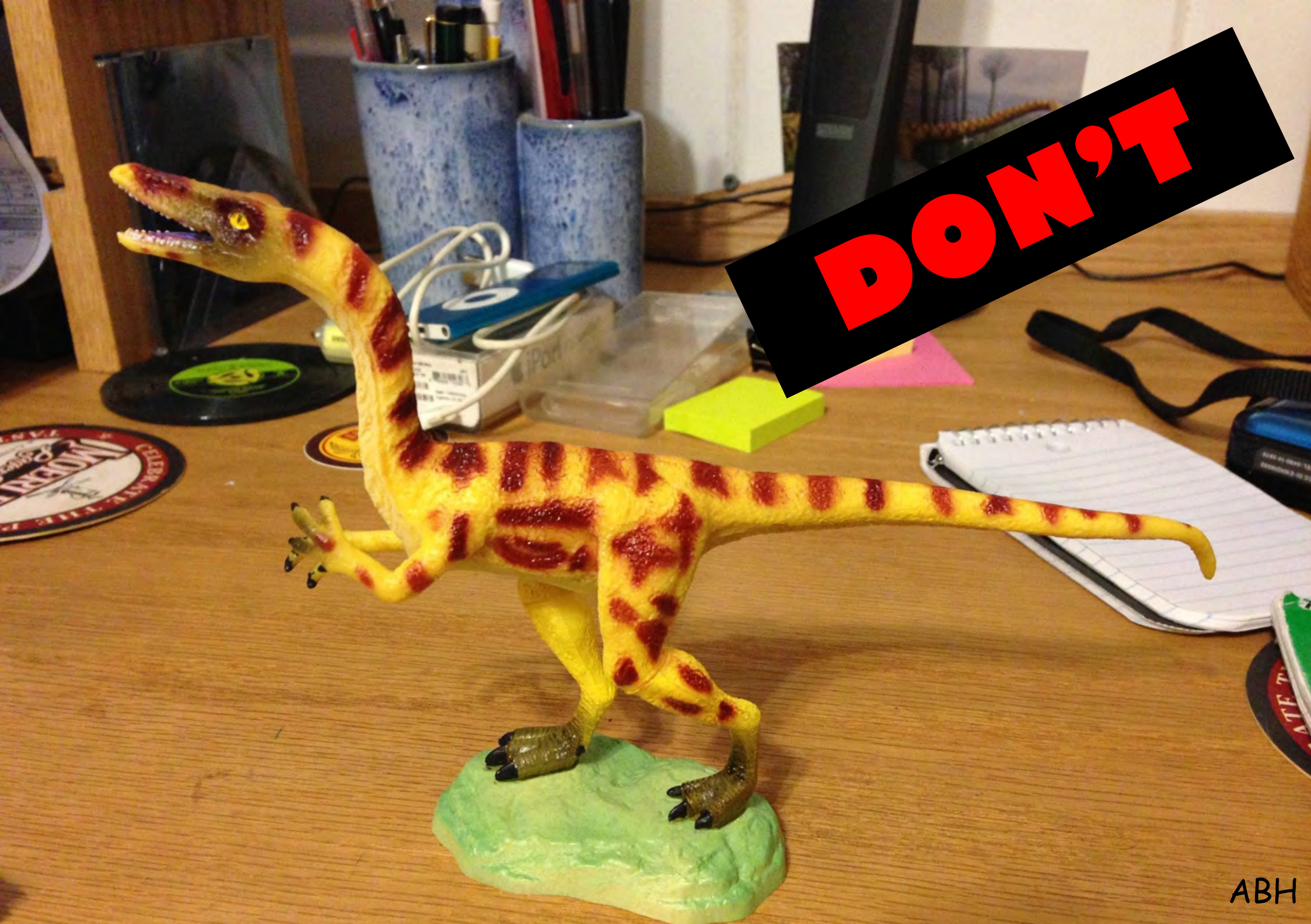

A bad shot (no scale; busy background; not even super-clear focus) 


\section{So the toy selection slide}

- Should have a title

- Should italicize your genus name (e.g.,

Coelophysis)

- And species, too! E.g., C. bauri

- Should have slides with multiple (labeled) views of your toy

- Should be named YourlastnameGenusToy

- Should not have instructions slides 


\section{Time to grade!}

\section{Submission status}

\begin{tabular}{ll} 
Submission status & Submitted for grading \\
\hline Grading status & Graded \\
\hline Due date & Friday, 4 November 2016, 5:00 PM \\
\hline Cut-off date & Monday, 7 November 2016, 5:00 PM \\
\hline Time remaining & Assignment was submitted 2 days 6 hours early \\
\hline Editing status & Student cannot edit this submission \\
\hline Last modified & Wednesday, 2 November 2016, 10:29 AM \\
\hline File submissions & - Des BaileyAnkylosaurusToy.pptx \\
\hline Submission comments & > Comments (0)
\end{tabular}




\section{The grader's most important question}

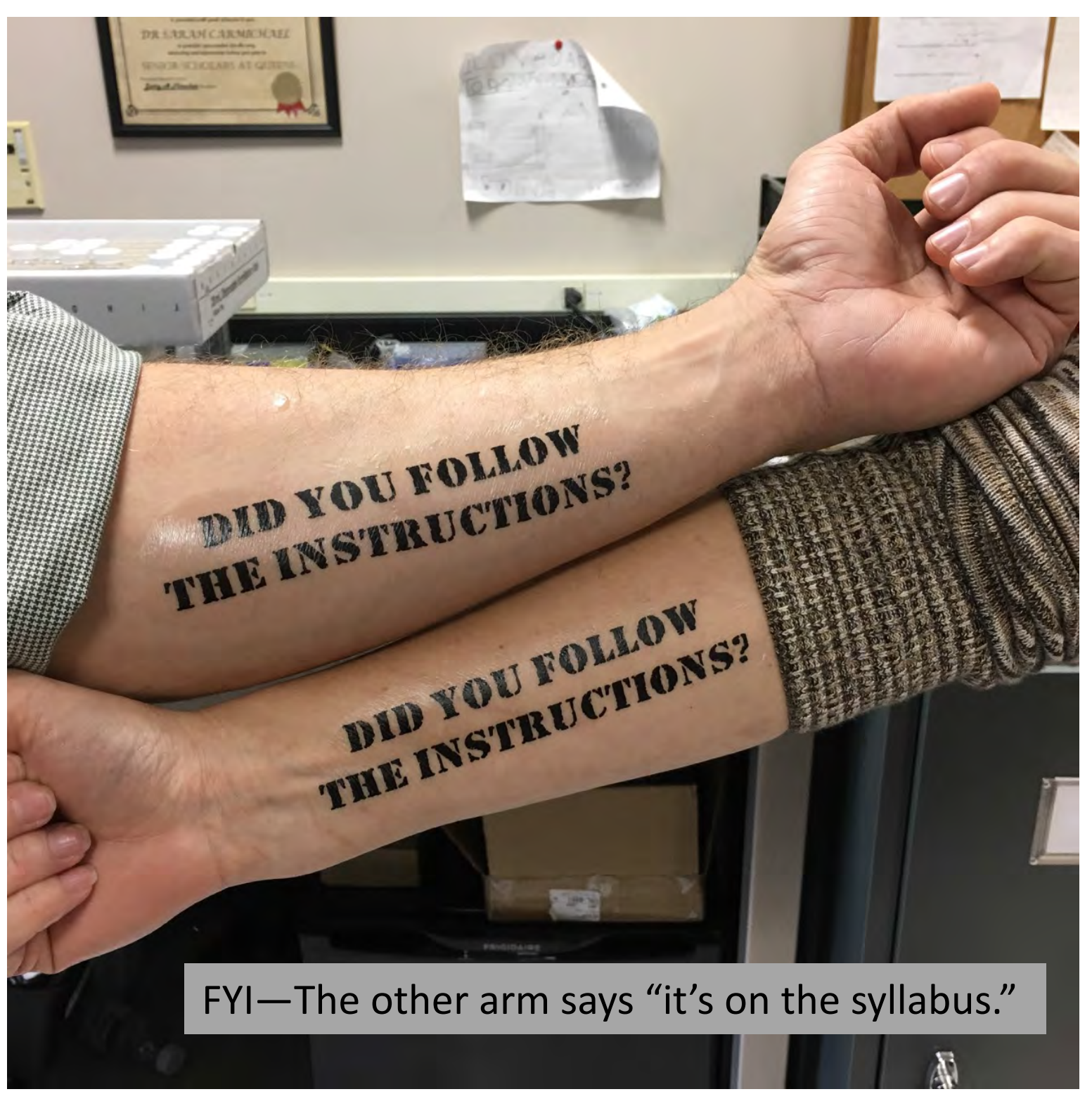




\section{Rubric set up in ASULearn}

Grade: $\quad$ Rubric for the "Dinosaur Toy Assignment" upload of the title slide plus three views of the specimen.

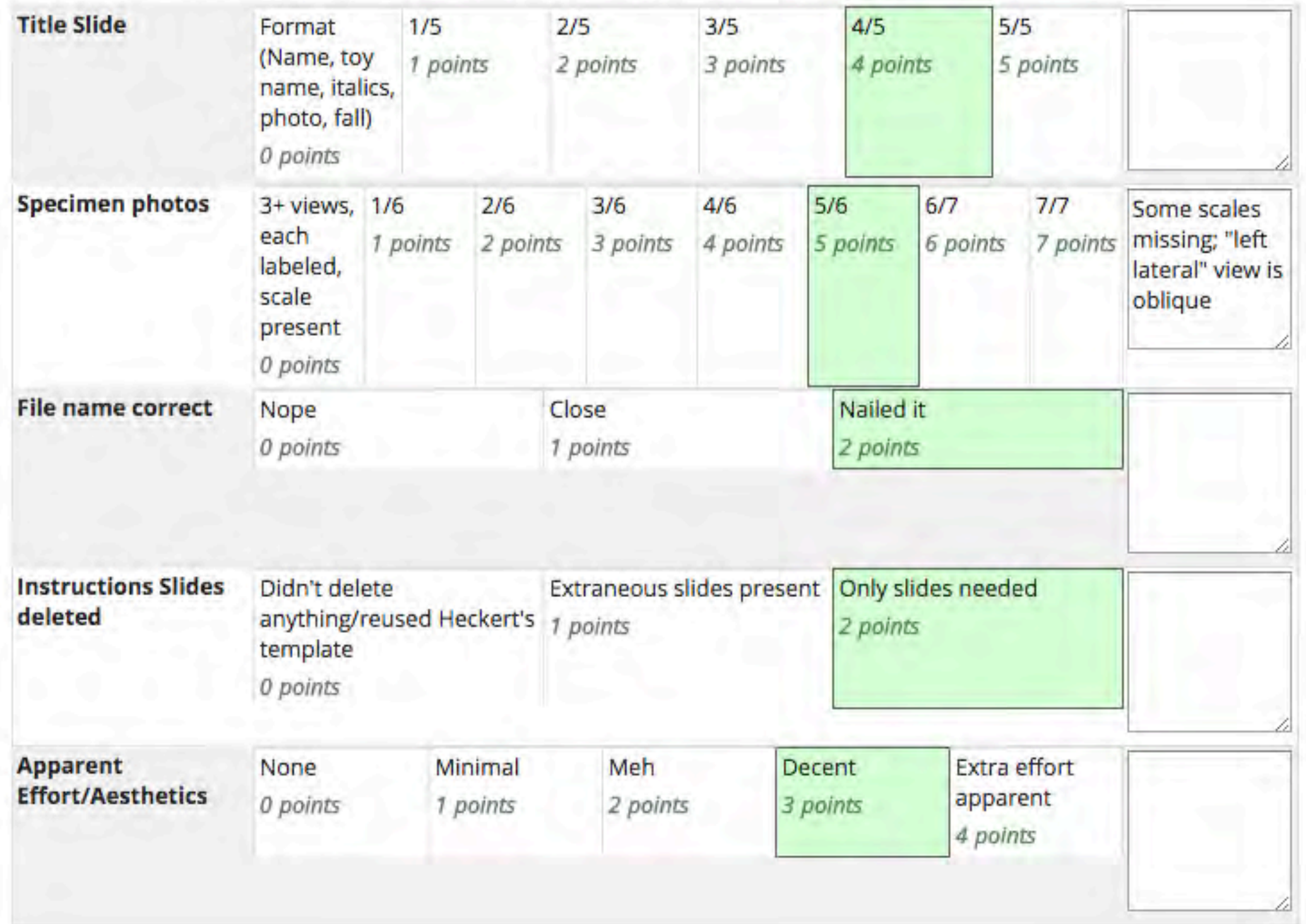




\section{Comments, etc.}

Current grade in gradebook

Grading student

4 out of 74

Feedback comments

Paragraph

B 1 |

4 国国

Is that animal definitely Ankylosaurus? If so, you should have a lot of fodder for your review.

Thus, if I disapprove of a "dinosaur" choice I can make comments here. 


\section{ABH's "mock-up"}

- Pros:

- Provides fairly unambiguous examples

- Educates students about Coelophysis

- Forces them to learn presentation software

- Cons

- A little too "plug \& chug" /"plug \& play"

- Does not evaluate writing per se

- References-what to do?

- Rubric hurts grade flexibility

- Notes

- I repeat the initial slides (instructions, title, views) in the mock-up, but we're skipping to the good stuff 


\section{Table of Contents}

- Title slide w/toy \& manufacturer, name, date

- Slides with toy in multiple views

- Specifications (scale \& measurements)

- Timescale slide

- Skeleton slide

- Reconstruction slide

- Paleogeographic map

- Cladogram slides (general; detailed)

- Linnaean classification slide

- Pros \& Cons slide

- Summary slide

- References slide 


\section{Grading first few slides}

Grade: Rubric for the dinosaur toy final upload

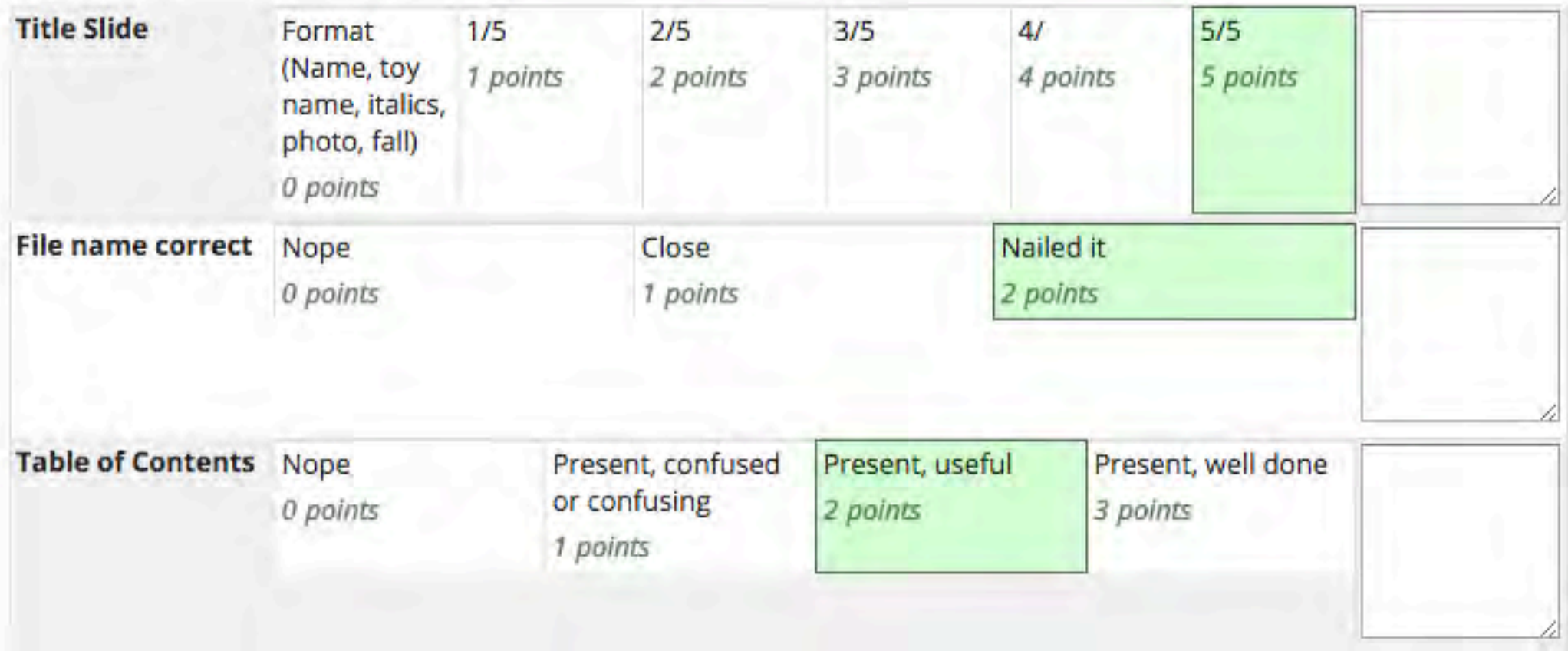

Mostly "free" points to help build a reserve if they lose "ticky-tack" points later 


\section{Specs}

Scale $=12.27272727273$

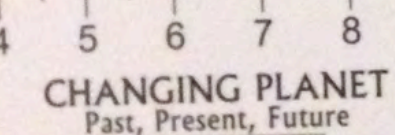

Past, Present, Future

Ol

(a)
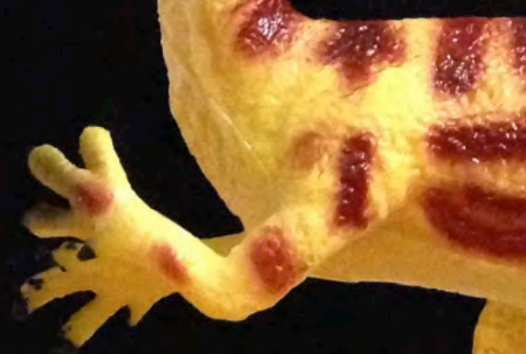

1
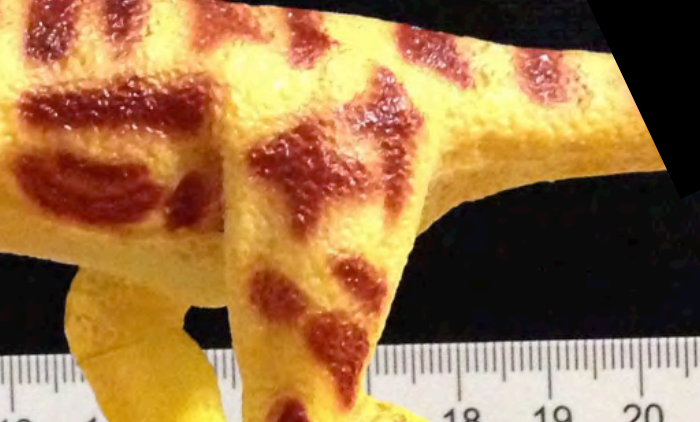

$\begin{array}{lllll}10 & 11 & 12 & 13 & 14\end{array}$ Bialnteractive.o.

$x-7$

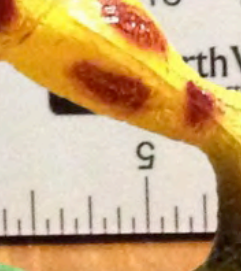
thV

\section{Problems:}

(1) No details/explanation

(2) Silly number

(3) No citation 


\section{Naming Coelophysis}

Coelophysis is one of the older names given to a dinosaur, it was named by E.D. Cope in 1887.

Cope, E.D., 1887, The dinosaurian genus Coelurus. American Naturalist, v. 21, p. 367-369

Cope, E.D., 1889, On a new genus of Triassic Dinosauria. American Naturalist, v. 23, p. 626.

***Just so you know, Coelophysis has a complex history. Cope referred his new species to Marsh's genus Coelurus in 1887, but in 1889 published (correctly) that they belonged in a different genus, so the species was named in 1887 even if the genus wasn't assigned until later.

And it gets more complicated from there.

Most popular dinosaurs were named in articles now linked from the Wikipedia or otherwise easily available $A B H$
1887]

Geology and Palaontology.

367

more or less rounded, still fitting into their original places, although the decayed connecting rocky matter has long since been removed. Most of the boulders have spheroidal or ellipsoidal forms, and resemble as much northern erratics, or perched blocks, as any seen within the drift zone of America or modern glacier regions of Europe. One of these boulders is about glacier regions of Europe. One of these boulders is about
thirty feet long, fifteen feet broad, and twenty feet high, perched on top of a rounded hummock, and resting on only a few small on top
points.

points.

When one compares the forms of these rocks south of the line of northern drift, and of others similar in the more southern Appalachians, and reads of the same in warm countries, as Ceylon and Brazil on the one hand, and, on the other, with those of the Swiss valleys and the greater and more wide-spread rounded surfaces of Norway, still in contact with living glaciers, -where he may see how unimportant a factor is the land-ice in gnawing away the old crystalline rocks, - one is forced to look upon the structure of both as more or less of common origin-atmospheric erosion, perhaps aided by currents, -although the latter region has been swept off by a brush of ice which has left scratches behind-F. W. Spencer, University of Missouri, Colymtra, Mo

The Dinosaurian Genus Colurus-This genus was described by Marsh, in 1871, from material obtained in the Jurassic deposit of Wyoming Territory. Characteristic bones not distinguishable as to genus from those described by Marsh are in my collection from New Mexico, probably from beds of Triassic age. They consist of nearly all parts of the skeleton, excepting jaws and teeth, and but little of the skull is determinable. The material is much more complete than that described by

The mate
Marsh.

The remains show that the genus Coelurus is a Dinosaurian, and I cannot agree with Professor Marsh's view "that Coelurus cannot be placed in any known order." " The ilium has the general character of that of the carnivorous suborder (Goniopoda), and the other parts of the skeleton confirm this reference. Such is the possession of compressed, strongly-curved claws, which were capable of very extensive flexion and extension. Coelurus is in fact allied to Megadactylus (Hitchcock) from the Trias of Massachusetts, differing principally, so far as determinable, in the form of the condyles of the femur. They are simple in Cœlurus, but in Megadactylus the external condyle has the double character seen in Megalosaurus. ${ }^{3}$

The vertebra are all of slender proportions, especially those of the neck and tail. These, with most of the bones of the 'Amer. Journal Sci. Arts, po, 339, Plate X.
isee Cope, Trans. Amer. Philosoph. Soc., xiv., 1870, Plate Xifl.

Title page from the 1887 article 


\section{NAMING DIPLODOCUS}

- Marsh (1878) Marsh OC. Principal characters of American Jurassic dinosaurs, Part I. American Journal of Science (series 3) 1878;16:411-416.

- The first skeleton was found in 1877 and was named Diplodocus longus ('long doublebeam'), by paleontologist $\bigcirc$. Charles Marsh in 1878.

- It was named along with other members of the Sauropod suborder.

- The most well know Diplodocus species are D. carnegii, D. hallorum, and D. longus.

Dipladocus longus, gen. et sp. nov.

This genus includes some Dinosaurs of very large size, and herbivorous in habit. It may be distinguished from the geneia already knowu by the eandal vertebras, which are elongated, deeply excavated below, and have double chevrons, witu both anterior and posterior rami. (Plate VIII, figures 3 and 4). To the last character, the generic name refers. The tibia, also, is a very characteristic bone, as it is deeply gronved above to receive the flbula. The feet in this genus are very similar to those of Morovaurus, ghown in Plate Vil.

The prosent apecies is based upon one posterior limb, abd the tail, of a single individnal. The limb, as extended before removal, mensured from the head of the fermur to the end of the wes over thirteen feet $\left(4^{M}\right)$. The femur was $1646^{\circ}$ men in length, and the tibia 1690min, Foor of the median cadal vertebre measured together thirty four inelies $\left(760^{\mathrm{mm}}\right)$, The first of these. or the fourteontb in the series, was oight and one-half

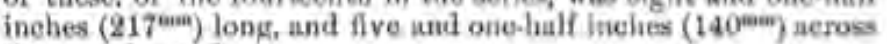
the anterior end.
Of this suborder, Sauropoda, four genera are well represented in the Museum of Yale College, and otliers apparently elosely allied, are indicated by remains from this conntry and Europe described by various authors. The genera dilantosaurus, (Titanosaurus), ${ }^{*}$ Apalosaurus and Morosaurus, have already been described by the writer, and with the new genus Dipladacus, defined below, are the most chameteristic American representatives of this group. Of these, Monosaurus is

*excerpts pages 412 \& 414 from Marsh's "Principal characters of American Jurassic dinosaurs." 


\section{Grading the next few}

\begin{tabular}{|c|c|c|c|c|c|c|c|c|c|}
\hline Specimen Photos & $\begin{array}{l}\text { 3+ views, } \\
\text { labeled, } \\
\text { scale } \\
\text { present, } \\
\text { clean } \\
\text { backgrounds } \\
0 \text { points }\end{array}$ & $\begin{array}{l}1 / 8 \\
1 \text { points }\end{array}$ & $\begin{array}{l}2 / 8 \\
2 \text { points }\end{array}$ & \begin{tabular}{|l}
$3 / 8$ \\
3 points
\end{tabular} & $\begin{array}{l}4 / 8 \\
4 \text { points }\end{array}$ & $\begin{array}{l}5 / 8 \\
5 \text { points }\end{array}$ & $\begin{array}{l}6 / 8 \\
6 \text { points }\end{array}$ & $\begin{array}{l}7 / 8 \\
7 \text { points }\end{array}$ & $\begin{array}{l}8 / 8 \\
8 \text { points }\end{array}$ \\
\hline Scale Slide & $\begin{array}{l}\text { Shot w/a } \\
\text { good scale, } \\
\text { scale stated, } \\
\text { math looks } \\
\text { reasonable/ } \\
\text { no silly } \\
\text { numbers, } \\
\text { cites a source } \\
\text { for size; } \\
\text { reasonable } \\
\text { calculations } \\
\text { of "real size"' } \\
0 \text { points }\end{array}$ & $\begin{array}{l}1 / 5 \\
1 \text { points }\end{array}$ & $\begin{array}{l}2 / \\
2\end{array}$ & 15 & $\begin{array}{l}3 / 5 \\
3 \text { poin }\end{array}$ & & $\begin{array}{l}4 / 5 \\
4 \text { points }\end{array}$ & $5 / 5$ & oints \\
\hline Naming slide & $\begin{array}{l}\text { Correct attribu } \\
\text { of name; scree } \\
\text { shot of title slic } \\
\text { reasonable } \\
\text { explanation } \\
0 \text { points }\end{array}$ & $\begin{array}{l}\text { ution } \\
\text { en } \\
\text { ide; }\end{array}$ & $\begin{array}{l}1 / 3 \\
1 \text { points }\end{array}$ & & $\begin{array}{l}2 / 3 \\
2 \text { point }\end{array}$ & & $\begin{array}{l}3 / 3 \\
3 p\end{array}$ & $\begin{array}{l}3 \\
\text { points }\end{array}$ & \\
\hline
\end{tabular}




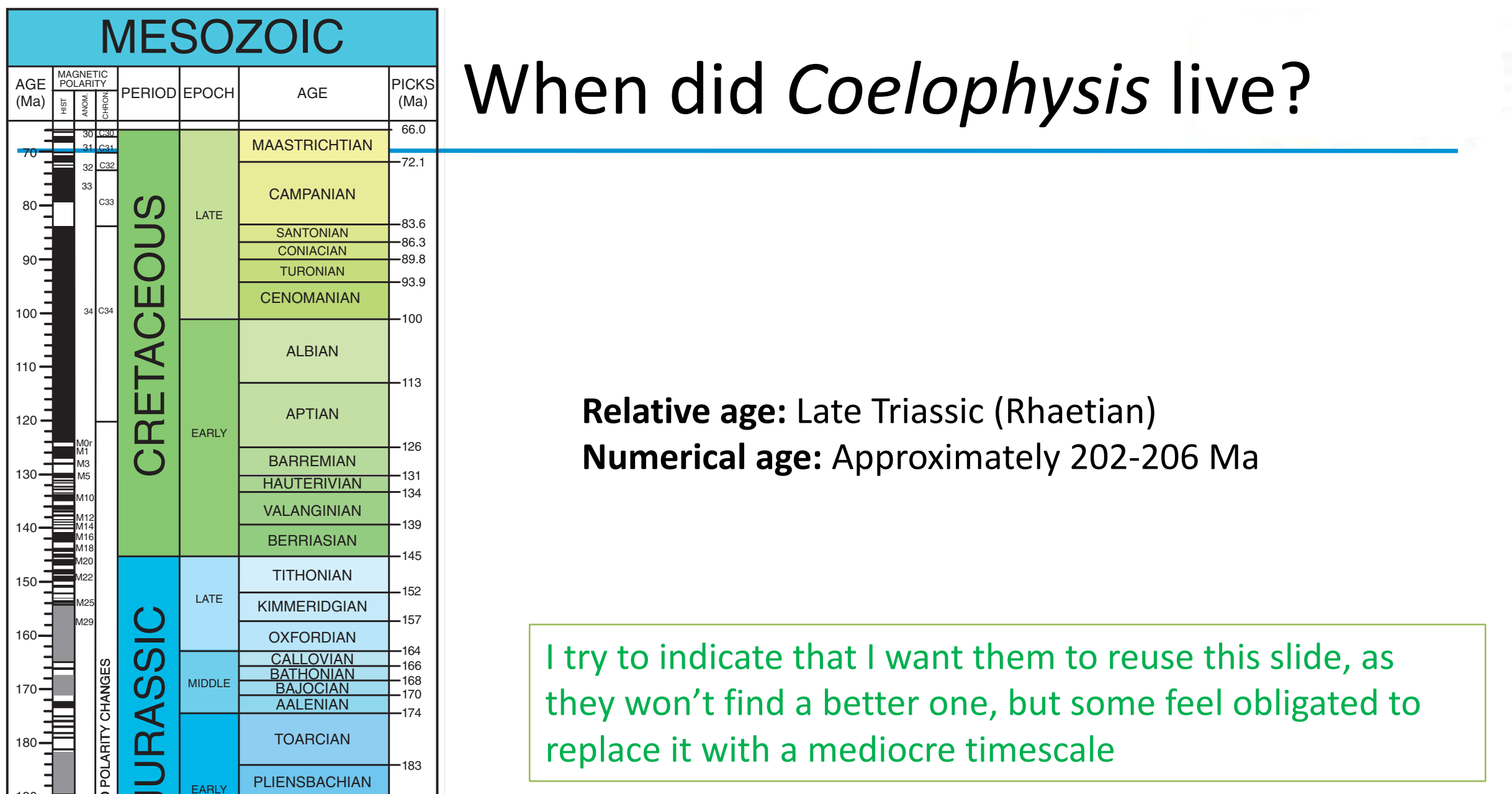

Coelophysis is known from the latest Triassic This is generally considered the Rhaetian and is approximately 205 million years ago.

$A B H$

Timescale from Geological Society of America (GSA, 2012) 
The paleogeographic distribution of $T$. rex is the Interior Western United States and parts of Canada. Locations where T. rex fossils have been found are: Colorado, New Mexico, Texas, Montana, Wyoming, South Dakota and Alberta.

T. Rex fossils are most commonly found in the Western United States. The most famous T. rex fossil was found in South Dakota (Sue).

The red dots indicate locations where Tyrannosaurus rex fossils have been discovered.

Locations provided by Sampson (2005) and Holtz \& Rey (2007) Maps Scotese (2014)

\section{Where did Tyrannosaurus Rex live?}

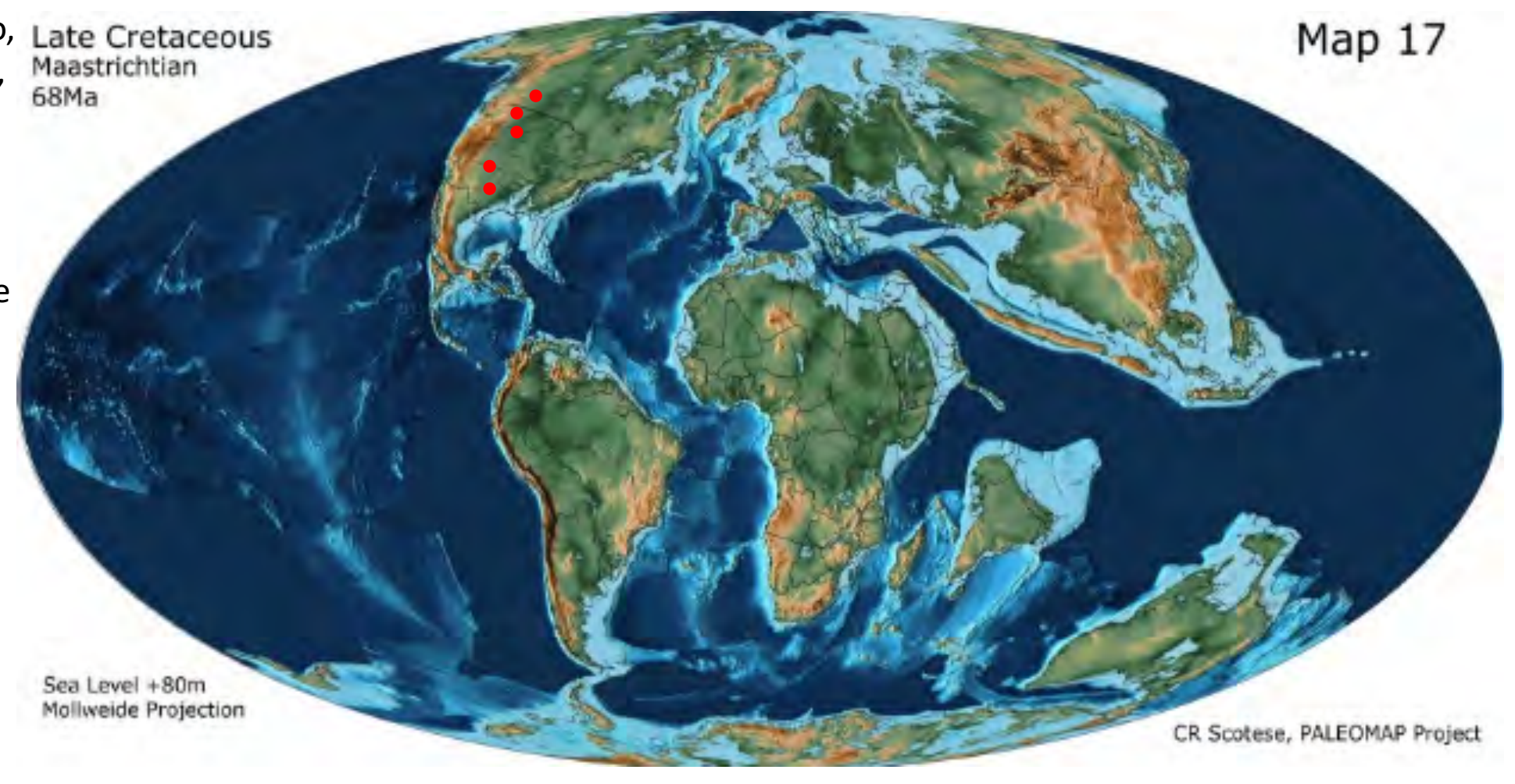




\section{What is known of Coelophysis?}

Reconstruction of the skeleton of Coelophysis by Matt Celeskey (in Rinehart et al., 2009)

Because of the many skeletons of Coelophysis from Ghost Ranch, essentially the entire skeleton is known.

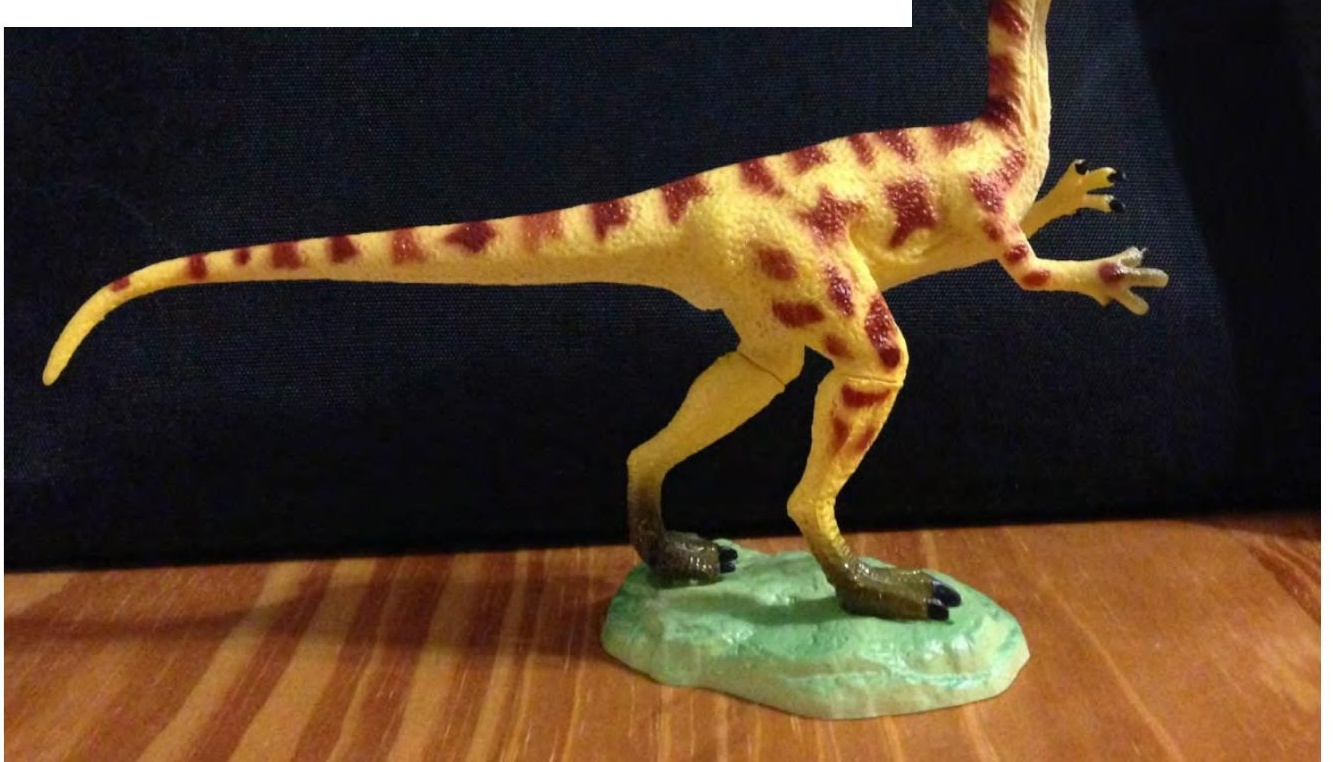




\section{What is known of Dakotaraptor?}

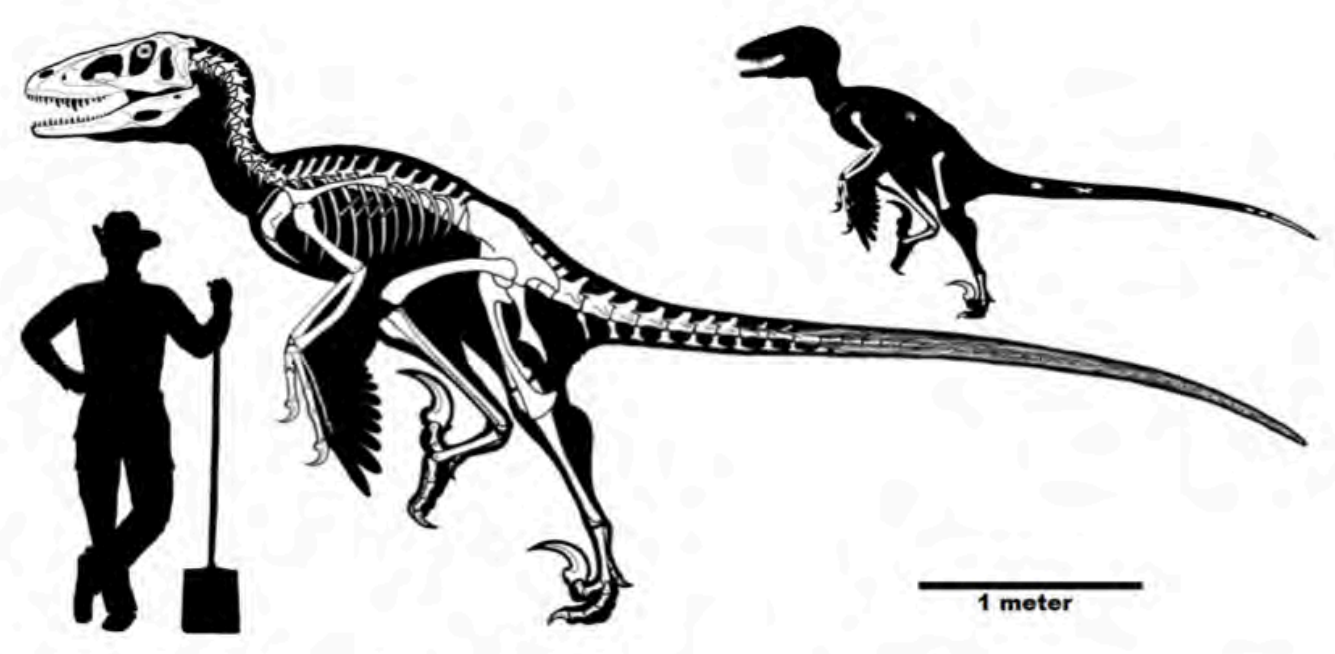

Figure 15. Skeletal reconstruction of Dakotaraptor holotype (PBMNH.P.10.113.T) based on available material for Utahraptor, Dromaeosaurus, Deinonychus, and Achillobator, demonstrating overall proportions and the large size of the creature. Preserved elements shown in insert.

Reconstruction of the skeleton

(from DePalma et al., 2015)

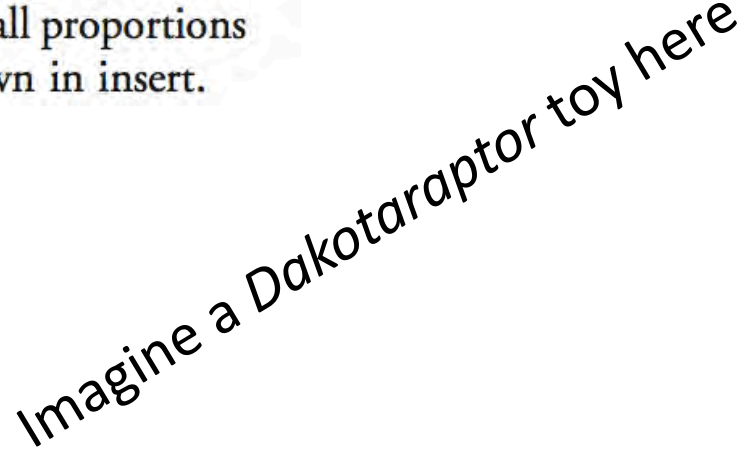




\section{Skeleton of Spinosaurus}

If you'd like, view video or next slide at minute 40 !

- Stromer used Allosaurus and Tyrannosaurus as models to the missing parts. Many older drawings and models ended up looking like Tyrannosaurus with a sail (Holtz 94).

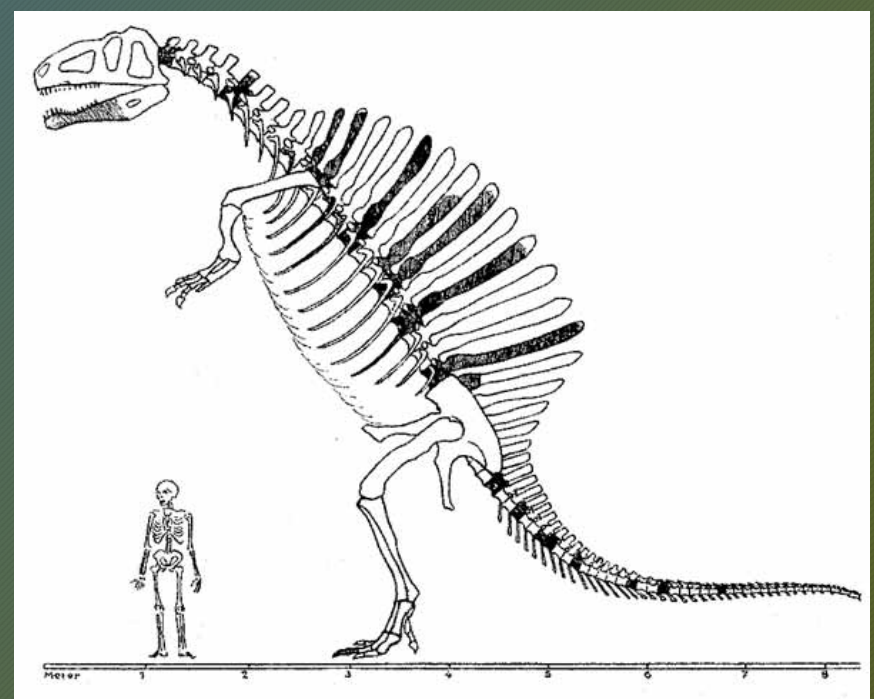

Reconstruction by Stromer, 1936

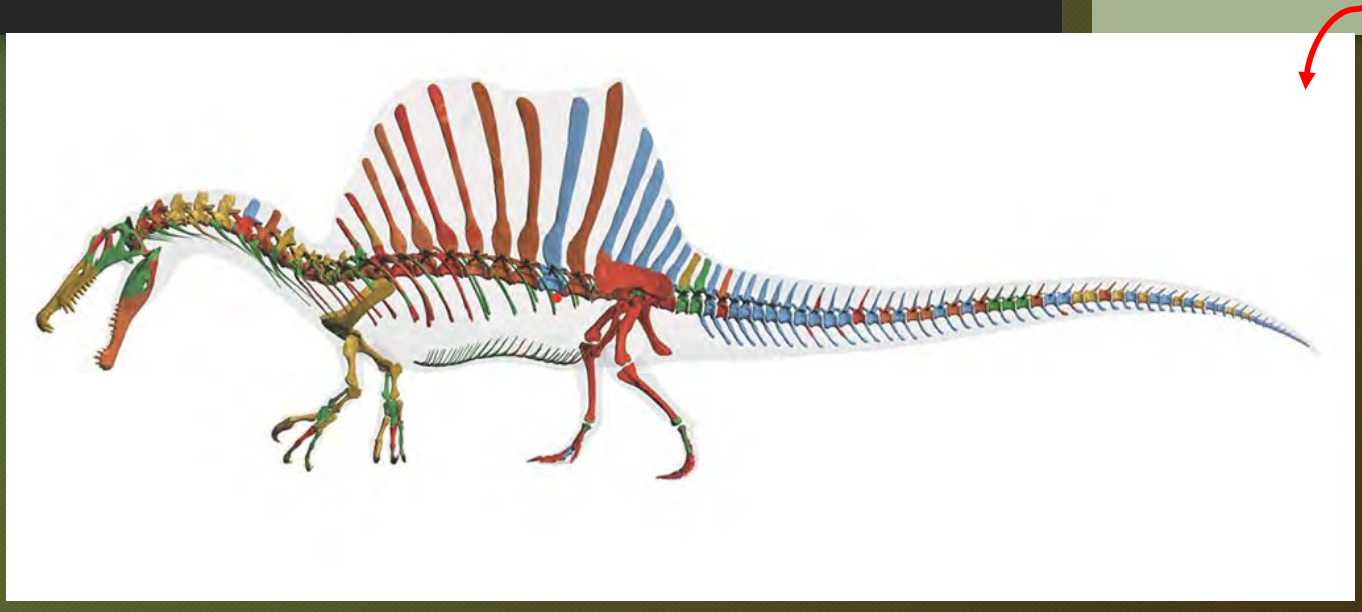

Looking at this reconstruction, you need to know:

- Red/rust-orange = neotype (specimen chosen as 'new holotype' when an original is destroyed) and Stromer's fossils

- Yellow = referred isolated remains (may not be proportional in scaling - basically place "fillers")

- Green = based on other spinosaurids (not from Spinosaurus)

- Blue = reconstructed (based on what we know - not actual fossils 


\begin{tabular}{|l|l|l|l|l|}
\hline Time scale slide & $\begin{array}{l}\text { Star on time scale is } \\
\text { correct; relative age; } 1 / 3 \\
\text { numerical age } \\
\text { Opoints }\end{array}$ & $\begin{array}{l}2 / 3 \\
2 \text { points }\end{array}$ & $\begin{array}{l}3 / 3 \\
3 \text { points }\end{array}$ \\
\hline $\begin{array}{l}\text { Paleogeographic } \\
\text { Map slide }\end{array}$ & $\begin{array}{l}\text { Star(s) on map; map } \\
\text { is right age (agrees } \\
\text { w/previous slide); } \\
\text { map is cited }\end{array}$ & $\begin{array}{l}\text { 1/3 points } \\
\text { Opoints }\end{array}$ & $2 / 3$ & $3 / 3$ \\
\hline $\begin{array}{l}\text { Skeletal } \\
\text { Reconstruction } \\
\text { slide }\end{array}$ & $\begin{array}{l}\text { Skeletal } \\
\text { reconstruction; } \\
\text { reasonable effort to } \\
\text { demonstrate what } \\
\text { is known; cites } \\
\text { reconstruction } \\
\text { Opoints }\end{array}$ & $2 / 3$ & 3 points \\
\hline
\end{tabular}




\section{Coelophysis in the dinosaur family tree}

Hadrosauridae

Iguanodontidae
Hypsilophodontia

Hypsilophodontia
Heterodontosauridae

Ornithopoda

Heteratopsiadae

$-$

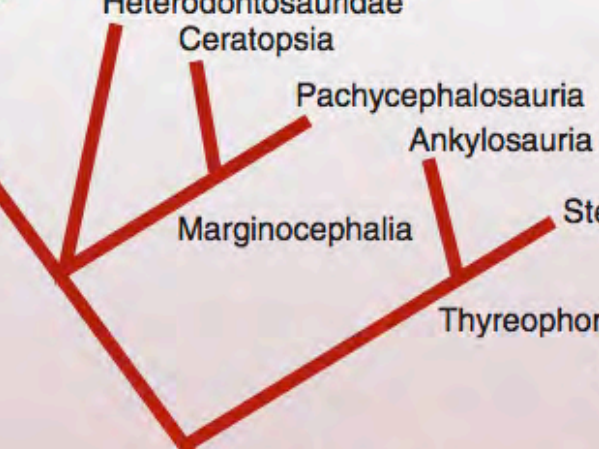

Titanosauria

1 Brachiosauridae
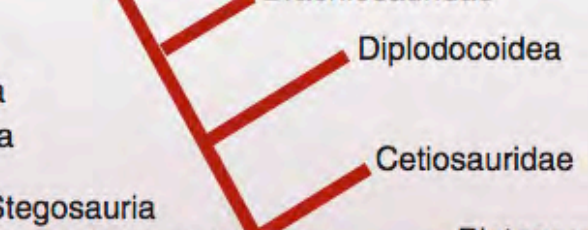

Stegosauria

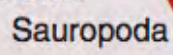

ra

Sauropodomorpha

Pisanosaurus

Ornithischia

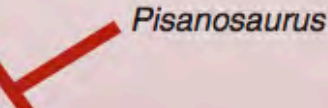

Herrerasauridae

Theropoda
Avıalae (Dıras)

Deinonychosauria

Oviraptorosauria

Maniraptora Ornithomimosauria

Tyrannosauroidea

Compsognathidae

Coelurosauria

Spinosauroidea

Ceratosauria

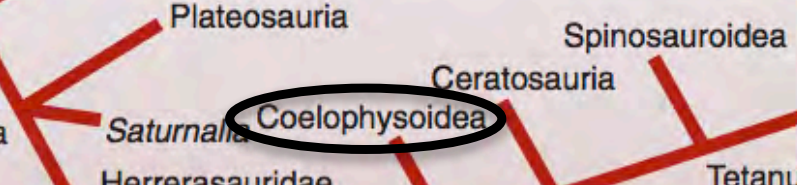

Tetanurae

(From Holtz, 2002)

Coelophysis is a coelophysoid theropod (circled)

This is a relatively primitive group of theropods, which are saurischian dinosaurs. 


\section{Coelophysis in the theropod family tree}

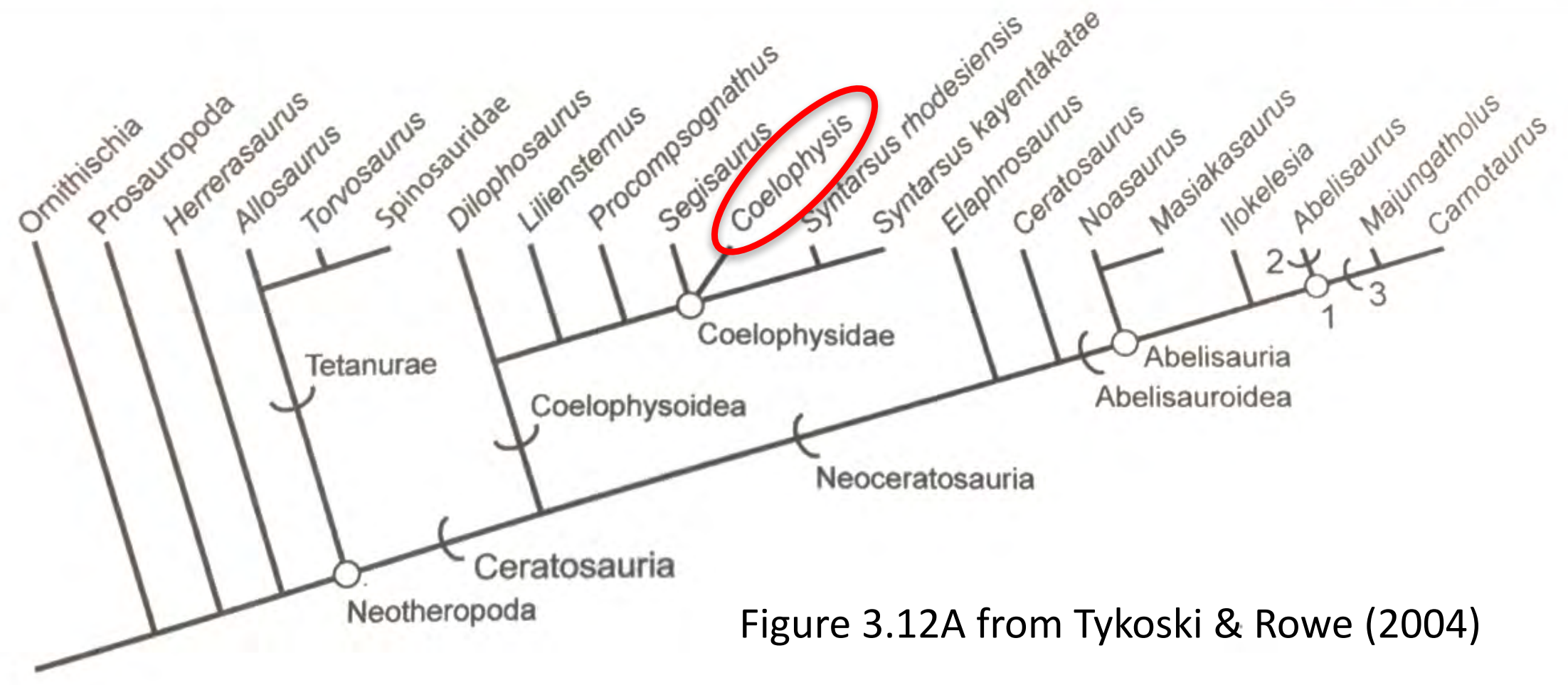

Coelophysis is one of the more derived coelophysoid theropods (circled) This is a relatively primitive group of theropods,

In the future I may ask them to tell me who their dinosaur is most closely related to, sister taxon, more "primitive," more derived, etc. 


\section{Coelophysis cladogram}

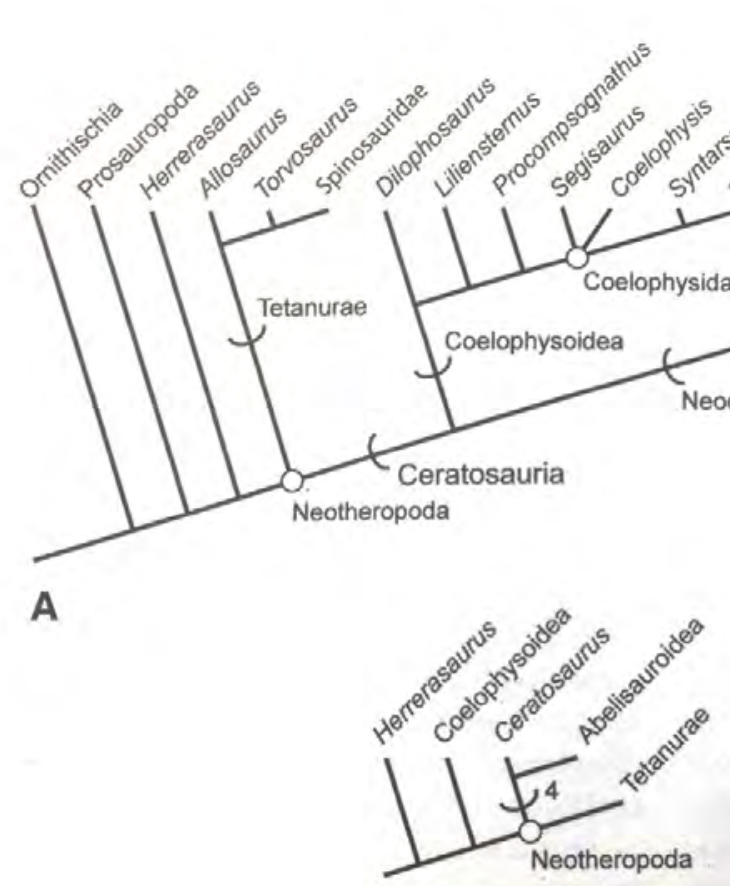

B

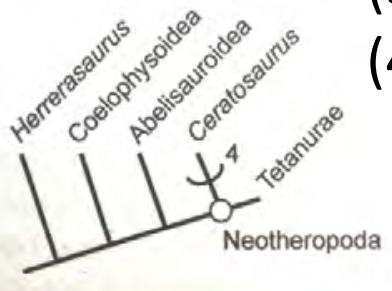

C

\section{Problems:}

(1) Crummy picture

(2) No citation

(3) No explanation

(4) WTH is Coelophysis on this?

FIGURE 3.12. Phylogenetic hypotheses of ceratosaurian relationships: A, Adams consensus of five equally most parsimonious trees generated by our analysis; tree length $=386, \mathrm{CI}=0.588, \mathrm{RI}=0.739$. Stem-defined clades indicated by arcs. Node-defined clades indicated by open circles at nodes. B, alternative phylogenetic hypothesis supported by Sampson et al. (2001). C, alternative hypothesis of ceratosaur relationships from Rauhut (1998) and Carrano and Sampson (1999). 1 = Abelisauridae; 2 = Abelisaurinae; 3 = Carnotaurinae; $4=$ Ceratosauria.

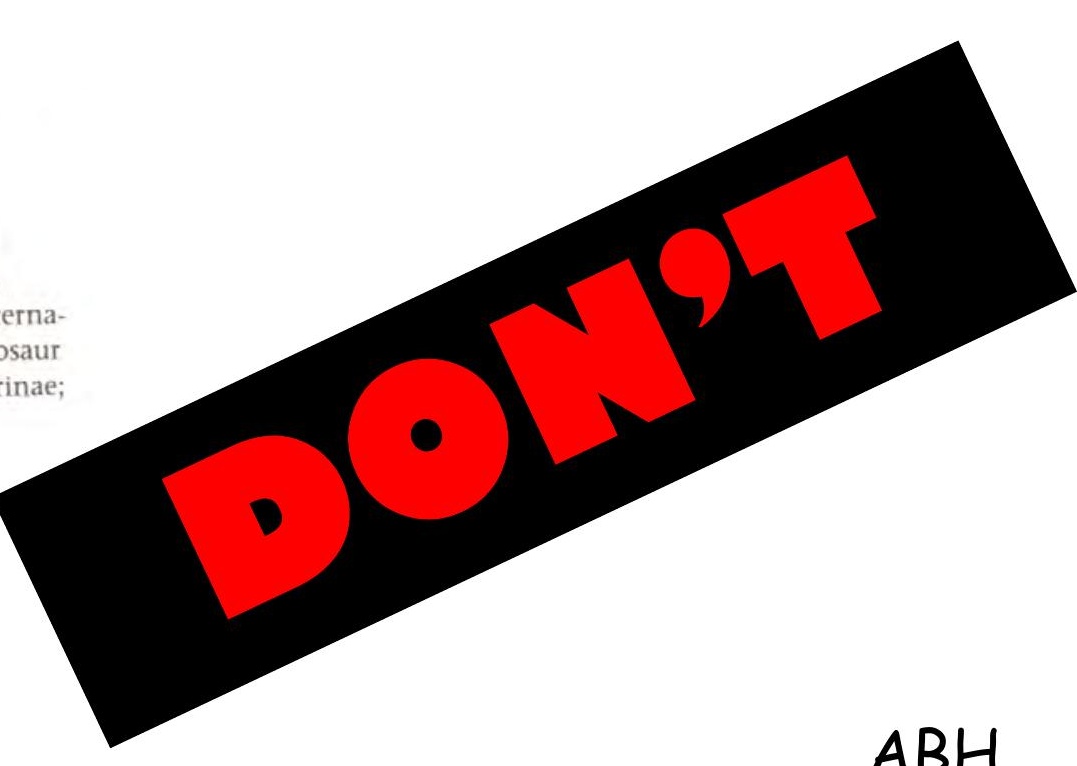




\section{Linnaean Taxonomy of Coelophysis}

- Kingdom: Animalia

-Phylum: Chordata

- Class: Reptilia

-Order: Theropoda

»Family: Coelophysidae

- Genus: Coelophysis

- Species: Coelophysis bauri (Cope)

Taxonomy follows Holtz (2002) 


\section{Life reconstruction of Coelophysis}

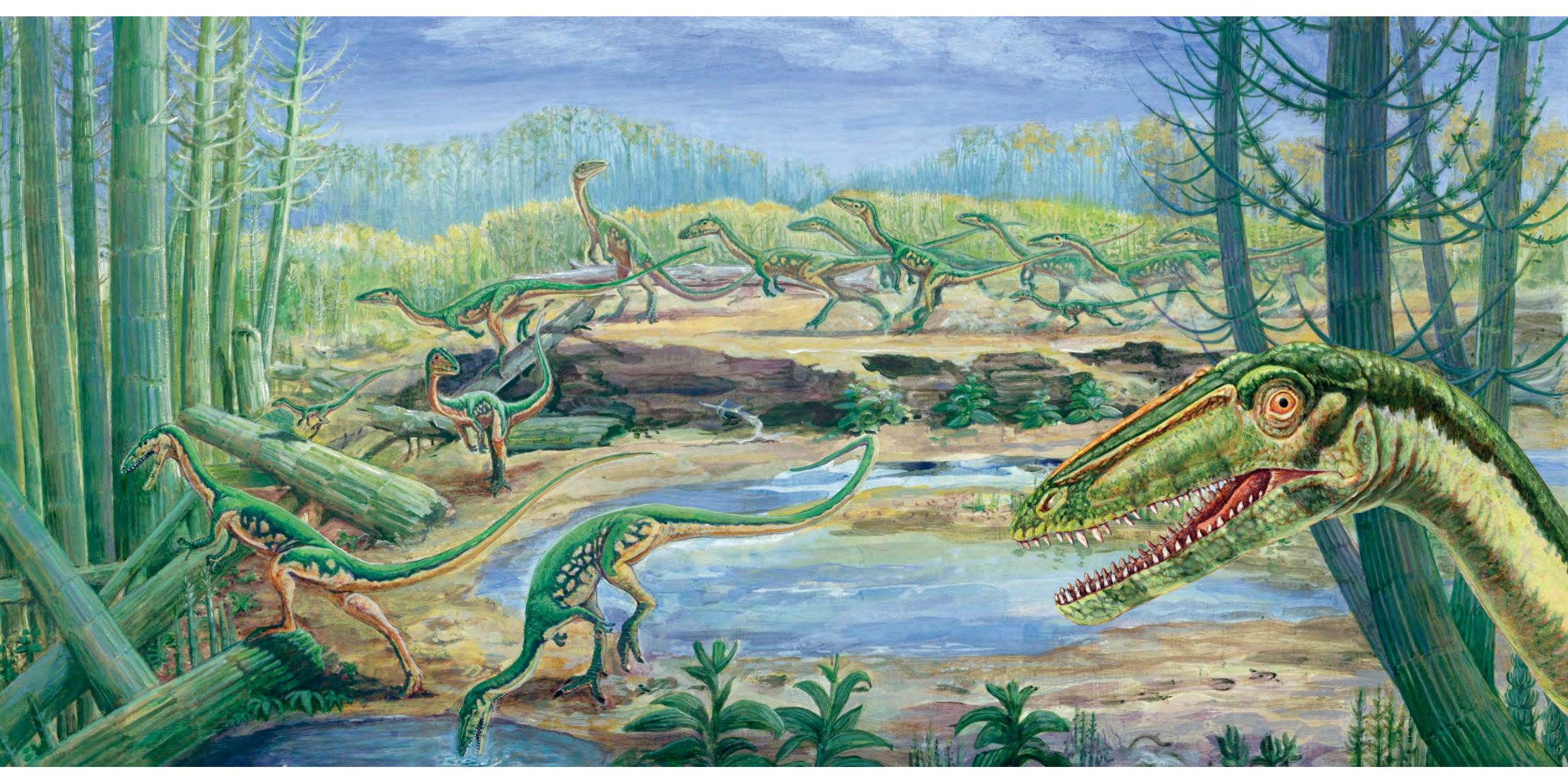

Reconstruction of a Coelophysis flock by Matt Celeskey

From Triassic New Mexico (Lucas, 2008). 


\section{Grading cladograms, taxonomy, etc.}

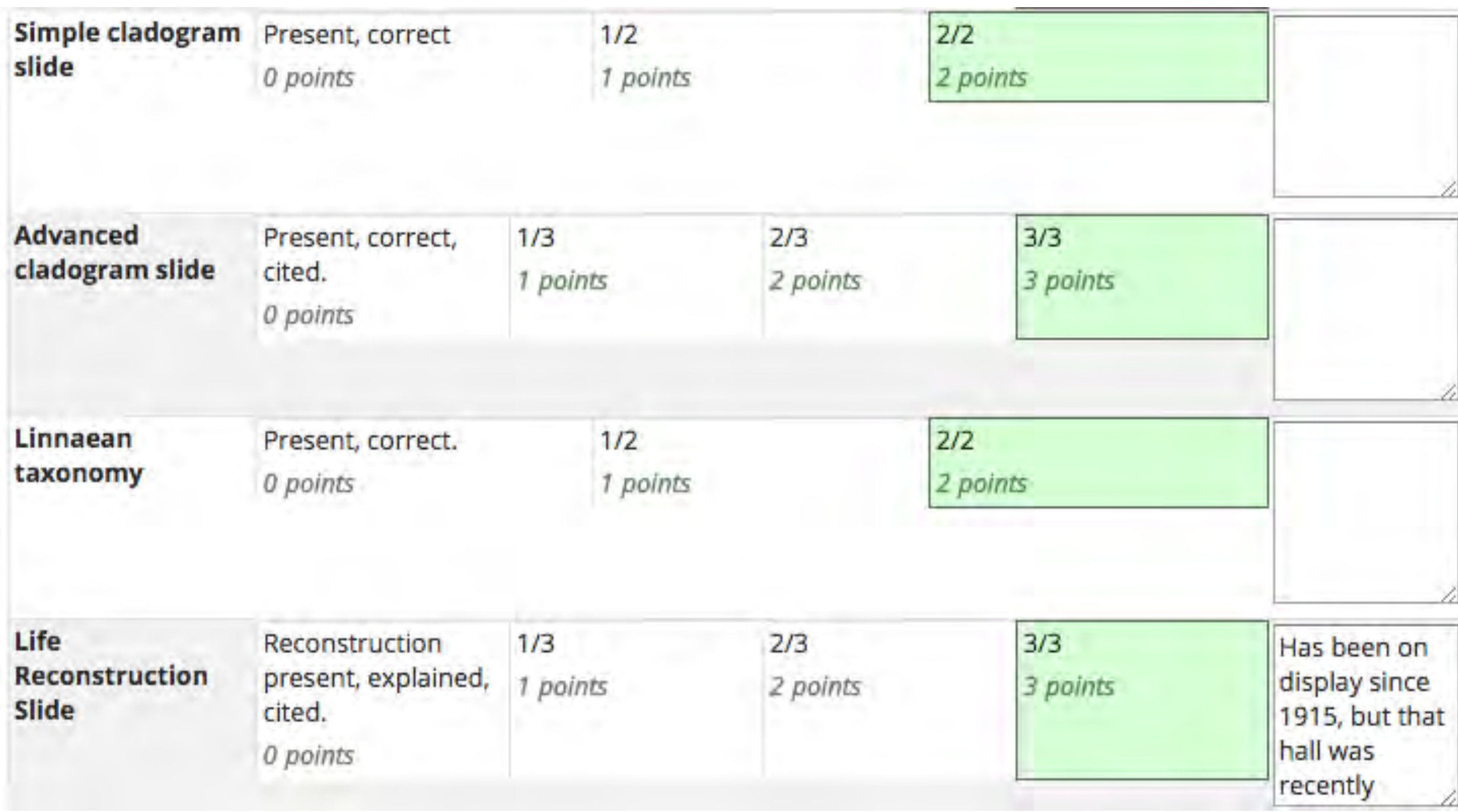




\section{Pros: Posture}

This is a generally "modern" dinosaur reconstruction

- Upright posture

-No tail-dragging

-Nothing obviously wrong

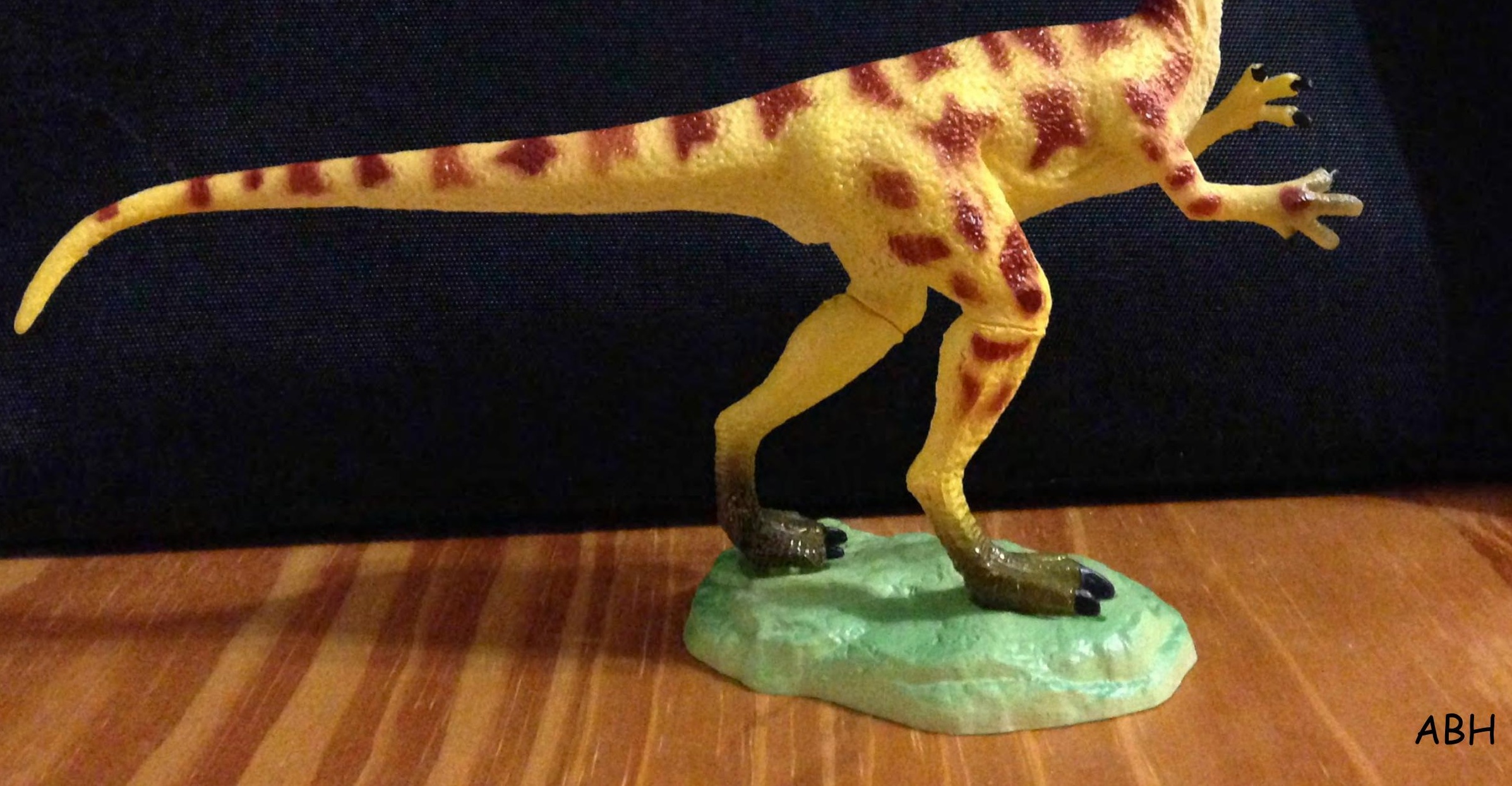




\section{Pros:}

Highlights of the toy include the hands (which did have four "fingers" because Coelophysis is a primitive theropod) and the base, which actually includes low-tech "tracks" 

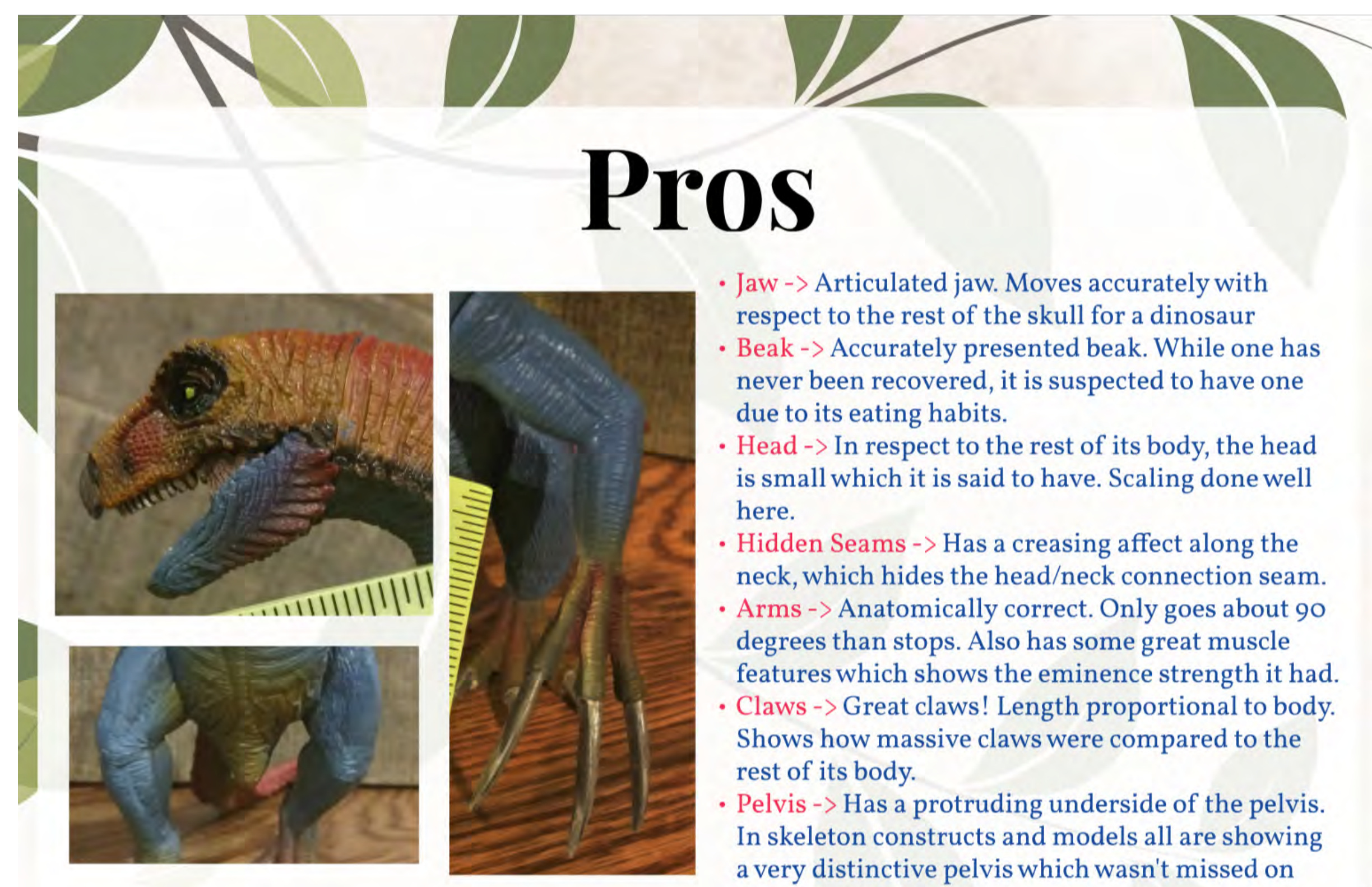

\section{Pros}

- Jaw -> Articulated jaw. Moves accurately with respect to the rest of the skull for a dinosaur

- Beak -> Accurately presented beak. While one has never been recovered, it is suspected to have one due to its eating habits.

- Head -> In respect to the rest of its body, the head is small which it is said to have. Scaling done well here.

- Hidden Seams -> Has a creasing affect along the neck, which hides the head/neck connection seam.

- Arms -> Anatomically correct. Only goes about 90 degrees than stops. Also has some great muscle features which shows the eminence strength it had. - Claws -> Great claws! Length proportional to body. Shows how massive claws were compared to the rest of its body.

- Pelvis $->$ Has a protruding underside of the pelvis. In skeleton constructs and models all are showing a very distinctive pelvis which wasn't missed on this toy model.

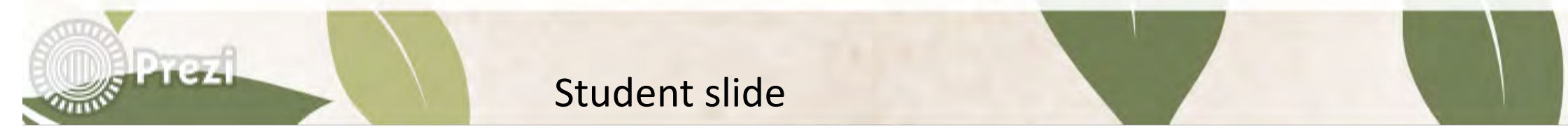




\section{Cons: Aesthetics}

An annoying feature of the toy is the marks just below the kneesit looks like a poor job of joining the legs to the rest of the body.

I doubt the color scheme is very realisticalthough the striping might be good, bright yellow and orange is not a terribly likely combination for a predator like Coelophysis. 


\section{CON= MANUS $\triangle \mathbb{N}$ ND PES (HANDS AND FEETI)}

- Diplodocus had claws on one digit of the front limb.

- The toy is missing this claw.

- This claw on the first digit is detached from the rest of the bones in the manus.

- The toy features fused metatarsals and phalanges.

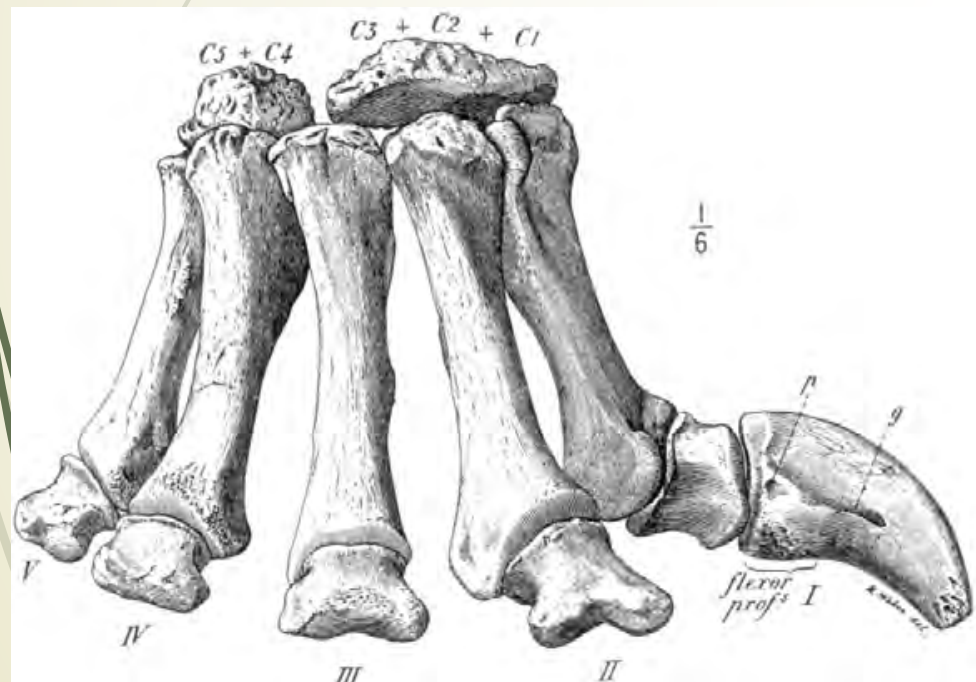

https://svpow.files.wordpress.com/2012/05/osborn1904manus-sacrum-caudals-fig 1 -manus-of-morosaurus-sp.jpeg

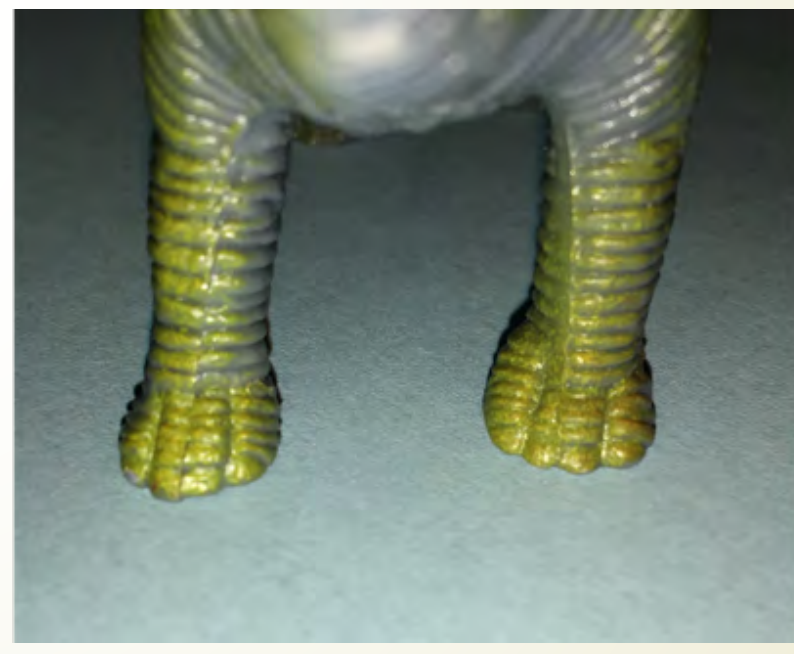

From Bonnan, M. F. (2003). 
- Coelophysis was a Triassic theropod dinosaur

- The Coelophysis toy by Geoworld@ looks superficially accurate

- This is one of the few theropod models with 4 fingers (that is correct)

- The scale and proportions are not especially accurate 


\section{Summary (cont)}

- Just to show that you can (and probably should) have more than 1 summary slide 


\section{Grading the evaluations}

\begin{tabular}{|c|c|c|c|c|c|c|c|c|}
\hline Pros \& cons & $\begin{array}{l}\text { Slide(s) of } \\
\text { pros and } \\
\text { cons of } \\
\text { model } \\
\text { present; } \\
\text { reasonable; } \\
\text { explained; } \\
\text { graded as } \\
\text { A-F. } \\
\text { O points }\end{array}$ & $\begin{array}{l}\text { Incomplete } \\
2 \text { points }\end{array}$ & $\begin{array}{l}\text { Half- } \\
@ \$ \$ \text { ed } \\
5 \text { points }\end{array}$ & $\begin{array}{l}\text { Dubious } \\
6 \text { points }\end{array}$ & $\begin{array}{l}\text { C-level } \\
7 \text { points }\end{array}$ & $\begin{array}{l}B \text { is for } \\
\text { bueno } \\
8 \text { points }\end{array}$ & $\begin{array}{l}\text { A-ish } \\
9 \text { points }\end{array}$ & $\begin{array}{l}\text { Outstanding } \\
10 \text { points }\end{array}$ \\
\hline Overall effort & $\begin{array}{l}\mathrm{ABH} \\
\text { assessment } \\
\text { of the } \\
\text { project as a } \\
\text { whole } \\
0 \text { points }\end{array}$ & $\begin{array}{l}\text { Incomplete } \\
2 \text { points }\end{array}$ & $\begin{array}{l}\text { Half- } \\
@ \$ \$ \text { ed } \\
5 \text { points }\end{array}$ & $\begin{array}{l}\text { Poor } \\
6 \text { points }\end{array}$ & $\begin{array}{l}\text { Typical } \\
\text { college } \\
\text { student } \\
\text { work } \\
7 \text { points }\end{array}$ & $\begin{array}{l}\text { Good } \\
\text { work } \\
\text { (top } \\
20 \% \text { of } \\
\text { class) } \\
8 \text { points }\end{array}$ & $\begin{array}{l}\text { Great } \\
\text { work } \\
\text { (top } \\
10 \% \text { of } \\
\text { class) } \\
9 \text { points }\end{array}$ & $\begin{array}{l}\begin{array}{l}\text { Outstanding } \\
\text { (top } 5 \% \text { ) }\end{array} \\
10 \text { points }\end{array}$ \\
\hline Summary Slide(s) & $\begin{array}{l}\text { Present, } \\
\text { reasonable, } \\
\text { convincing, } \\
\text { balanced } \\
0 \text { points }\end{array}$ & $\begin{array}{l}1 / 4 \\
1 \text { points }\end{array}$ & & $\begin{array}{l}2 / 4 \\
2 \text { points }\end{array}$ & & $\begin{array}{l}3 / 4 \\
3 \text { points }\end{array}$ & & $\begin{array}{l}4 \\
\text { ooints }\end{array}$ \\
\hline
\end{tabular}

This is where a good project that spaced out a couple details makes up ground. 


\section{References}

Cope, E.D., 1887, The dinosaurian genus Coelurus. American Naturalist, v.

21, p. 367-369

Cope, E.D., 1889, On a new genus of Triassic Dinosauria. American Naturalist, v. 23, p. 626.

Holtz, T.R. Jr., 2002, Chasing Tyrannosaurus and Deinonynchus around the tree of life: Classifying Dinosaurs. pp. 31-38 in Dinosaurs: The science behind the stories. AGU

Holtz, T.R. Jr. \& Rey, L.V., 2008, Dinosaurs, the most complete up-to-date encyclopedia for dinosaur lovers of all ages. Random House, 428 pp.

Rinehart, L. F., Lucas, S. G., Heckert, A. B., Spielmann, J. A., and Celeskey, M. D. 2009, The paleobiology of Coelophysis bauri (Cope) from the Upper Triassic (Apachean) Whitaker quarry, New Mexico, with detailed analysis of a single quarry block: New Mexico Museum of Natural History and Science Bulletin, v. 45, 260 pp.

Tykoski, R. S., and Rowe, T., 2004, Ceratosauria, in Weishampel, D. B., Dodson, P., and Osmólska, H., eds., The Dinosauria: Second Edition: Berkeley, University of California Press, p. 47-70. 


\section{Grading nuts-and-bolts}

\begin{tabular}{|c|c|c|c|c|c|c|}
\hline Reference slide(s) & $\begin{array}{l}\text { Present, } \\
\text { complete, } \\
\text { reasonable } \\
\text { format, } \\
\text { shows } \\
\text { investment in } \\
\text { project; } \\
\text { scholarly } \\
\text { sources. } \\
0 \text { points }\end{array}$ & $1 / 5$ & $\begin{array}{l}2 / 5 \\
2 \text { points }\end{array}$ & $\begin{array}{l}3 / 5 \\
3 \text { points }\end{array}$ & $\begin{array}{l}4 / 5 \\
4 \text { points }\end{array}$ & $\begin{array}{l}5 / 5 \\
5 \text { points }\end{array}$ \\
\hline Creativity & $\begin{array}{l}\text { Apparent } \\
\text { creativity } \\
\text { O points }\end{array}$ & $\begin{array}{l}\text { Simply reused } \\
\text { ABH slides } \\
1 \text { points }\end{array}$ & $\begin{array}{l}\text { Not } \\
\text { app } \\
2 p c\end{array}$ & & $\begin{array}{l}\text { Reasonably } \\
\text { creative } \\
3 \text { points }\end{array}$ & $\begin{array}{l}\text { Particularly } \\
\text { creative } \\
4 \text { points }\end{array}$ \\
\hline Nomenclature & $\begin{array}{l}\text { Proper use of } \\
\text { italics and } \\
\text { capitals } \\
0 \text { points }\end{array}$ & $\begin{array}{l}\text { T. Rex or } \\
\text { similar gaffes; } \\
\text { major issues. } \\
1 \text { points }\end{array}$ & $\begin{array}{l}\text { Distra } \\
\text { of } \\
\text { italics/ } \\
2 \text { poin }\end{array}$ & italization & $\begin{array}{l}\text { Decent grasp } \\
\text { of taxonomic } \\
\text { rules } \\
3 \text { points }\end{array}$ & $\begin{array}{l}\text { Great, no } \\
\text { issues } \\
\text { w/taxonomy } \\
4 \text { points }\end{array}$ \\
\hline
\end{tabular}




\section{Final grade sheet}

Current grade in gradebook

Grading student

\section{Feedback comments}

\begin{tabular}{|c|c|c|c|c|c|c|c|c|}
\hline $\begin{array}{l}\text { Grammar, } \\
\text { proofreading, etc. }\end{array}$ & $\begin{array}{l}\text { Reader's overall } \\
\text { experience } \\
0 \text { points }\end{array}$ & $\begin{array}{l}\text { Challengin } \\
\text { major issu } \\
1 \text { points }\end{array}$ & $\begin{array}{l}\text { gg- } \\
\text { les }\end{array}$ & $\begin{array}{l}\text { Significant } \\
\text { errors present; } \\
\text { distracting. } \\
2 \text { points }\end{array}$ & $\begin{array}{l}\text { Reas } \\
\text { writi } \\
\text { typo } \\
\text { othe } \\
3 \text { po }\end{array}$ & $\begin{array}{l}\text { sonable } \\
\text { ing but with } \\
\text { s and/or } \\
\text { is issues } \\
\text { ints }\end{array}$ & $\begin{array}{l}\text { Clear writing, } \\
\text { careful } \\
\text { proofreading } \\
\text { evident. } \\
4 \text { points }\end{array}$ & $\begin{array}{l}\text { The "Triassic" } \\
\text { typo shoes up } \\
\text { several times; } \\
\text { distracting. }\end{array}$ \\
\hline $\begin{array}{l}\text { Instructions slides } \\
\text { deleted }\end{array}$ & $\begin{array}{l}\text { Didn't delete } \\
\text { anything/reused } \\
0 \text { points }\end{array}$ & template & $\begin{array}{l}\text { Extr } \\
1 p c\end{array}$ & $\begin{array}{l}\text { aneous slides pre } \\
\text { ints }\end{array}$ & & $\begin{array}{l}\text { Only slides } \\
2 \text { points }\end{array}$ & needed & \\
\hline
\end{tabular}

92.05

6 out of 74

Paragraph + $\mathrm{B} \mid \boldsymbol{I}$ :

Only the second project I graded; seems pretty solid. 


\section{Above \& Beyond}

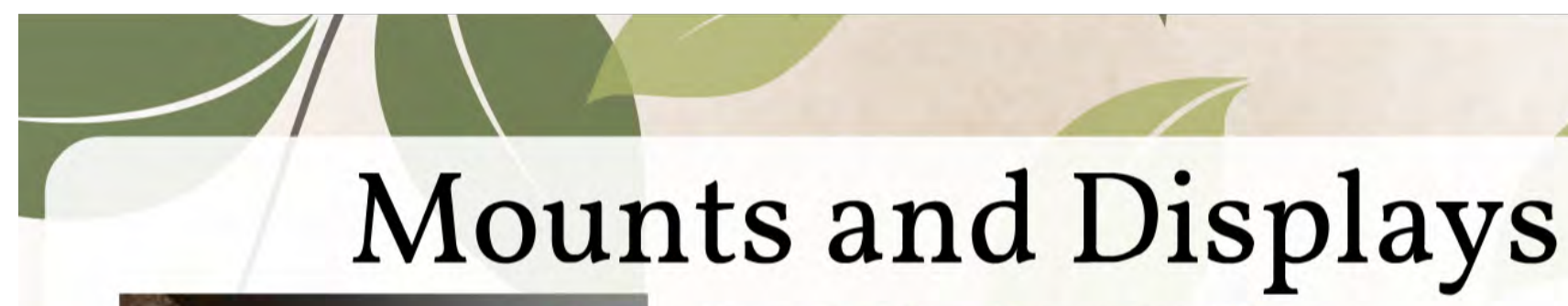

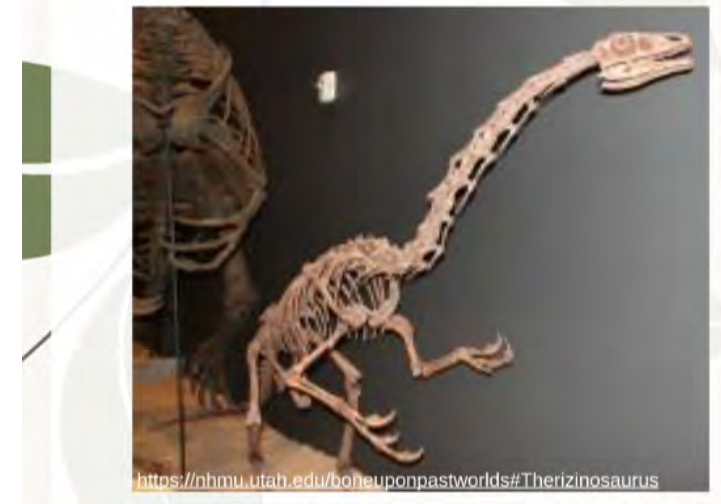

Natural History Museum of Utah, Rio Tinto Center

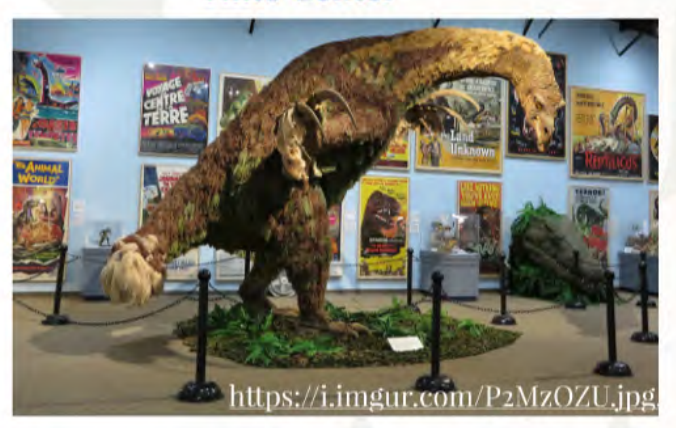

Dinosaur Museum in Blanding, UT

Nagoya City Science Museum, from Gifu, Japan

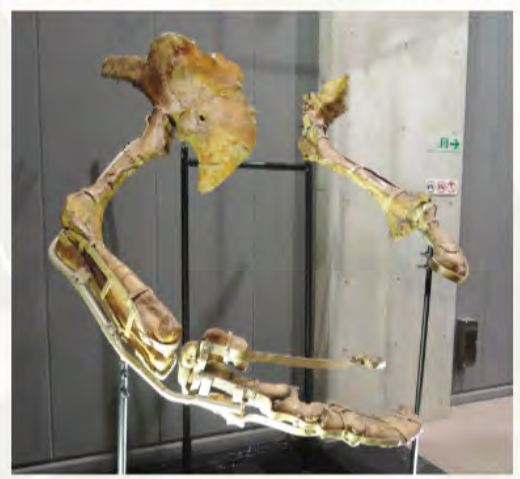

Australian Museum by Robert Jones

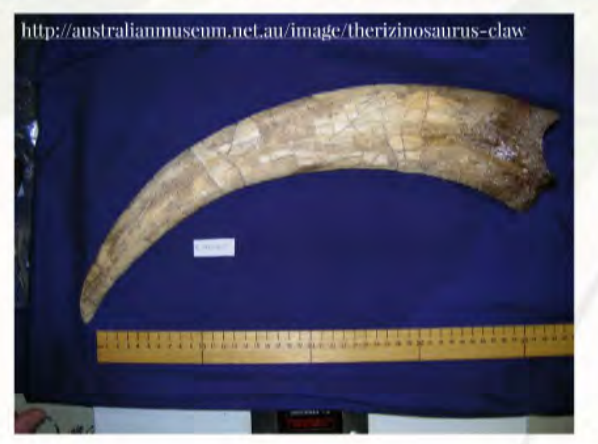

The Wyoming Dinosaur Center

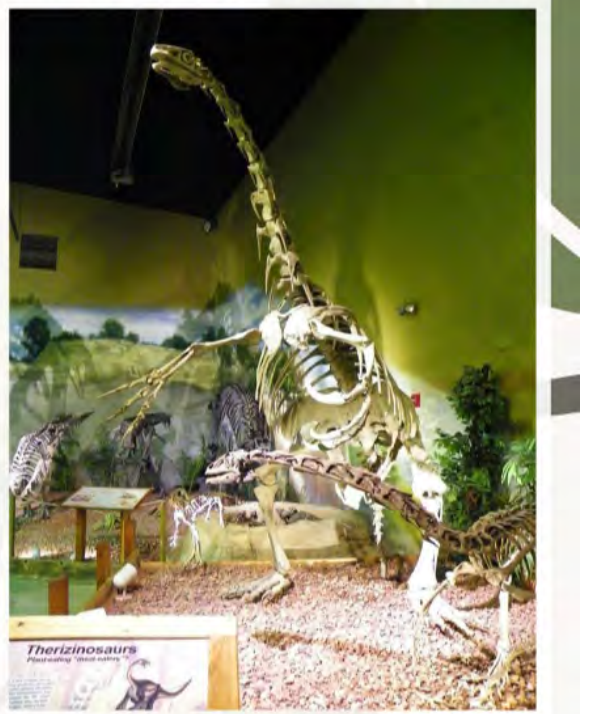

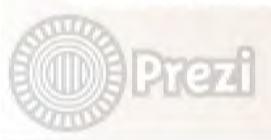
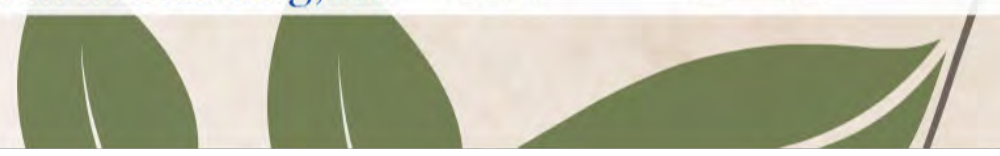

Student Slide 


\section{From the horses' mouths}

- Needs Improvement:

- Slightly more forgiving with grading, effort should matter.

- More project explanation.

- A little more explanation of what he wants from projects not just requirements

- More detail on assignments he wants completed maybe. 


\section{From the horses' mouths}

- Things done well:

- Projects were very helpful and fun.

- Visuals used, as well as projects given were extremely helpful.

- Well organized and materials given/projects on ASU were very relevant and helpful.

- I enjoyed all of the creative projects and ability to study the dinosaurs we had interest in.

- I enjoyed the project greatly because I cannot express myself as well I would like to in a paper as I can in a creative project like this one 


\section{Conclusions - the toy assignment helps}

- ...demonstrate proficiency in acquiring, interpreting, and disseminating dinosaur knowledge.

- ...incorporate scientific, especially geological perspective into the educational experience at ASU.

- Get 250-300 credit hours/offering w/o lab.

- Maintain standards w/out reading 80+ papers.

- Force a few more folks to face the " $e$ " word, deep time, and other scientific concepts.

- Students appear to enjoy it 


\section{Pros \& Cons}

- Pros:

- Scalable

- Difficult to plagiarize (\& archivable)

- Could go into "e-portfolio"

- Requires students to learn presentation software

- Educates students about Coelophysis

- Cons

- "Plug-and-chug"/Rubric hurts grade flexibility

- Does not evaluate writing per se

- References-what to do?

- Future directions:

- Toy manufacture date vs. apparent "scientific age" (e.g, 1980s toy, 1960s knowledge)

- Dissemination? 


\section{Acknowledgments}

- Department of Geology, especially Dr. Bill Anderson for encouraging me to develop GLY 1842 Dinosaurs: Then \& Now.

- The Adminisphere for putting GLY 1842 into a non-science theme.

- Many "A" students for providing project successes and sharing their work.

- Session organizers for including this whether or not it's transformative. 

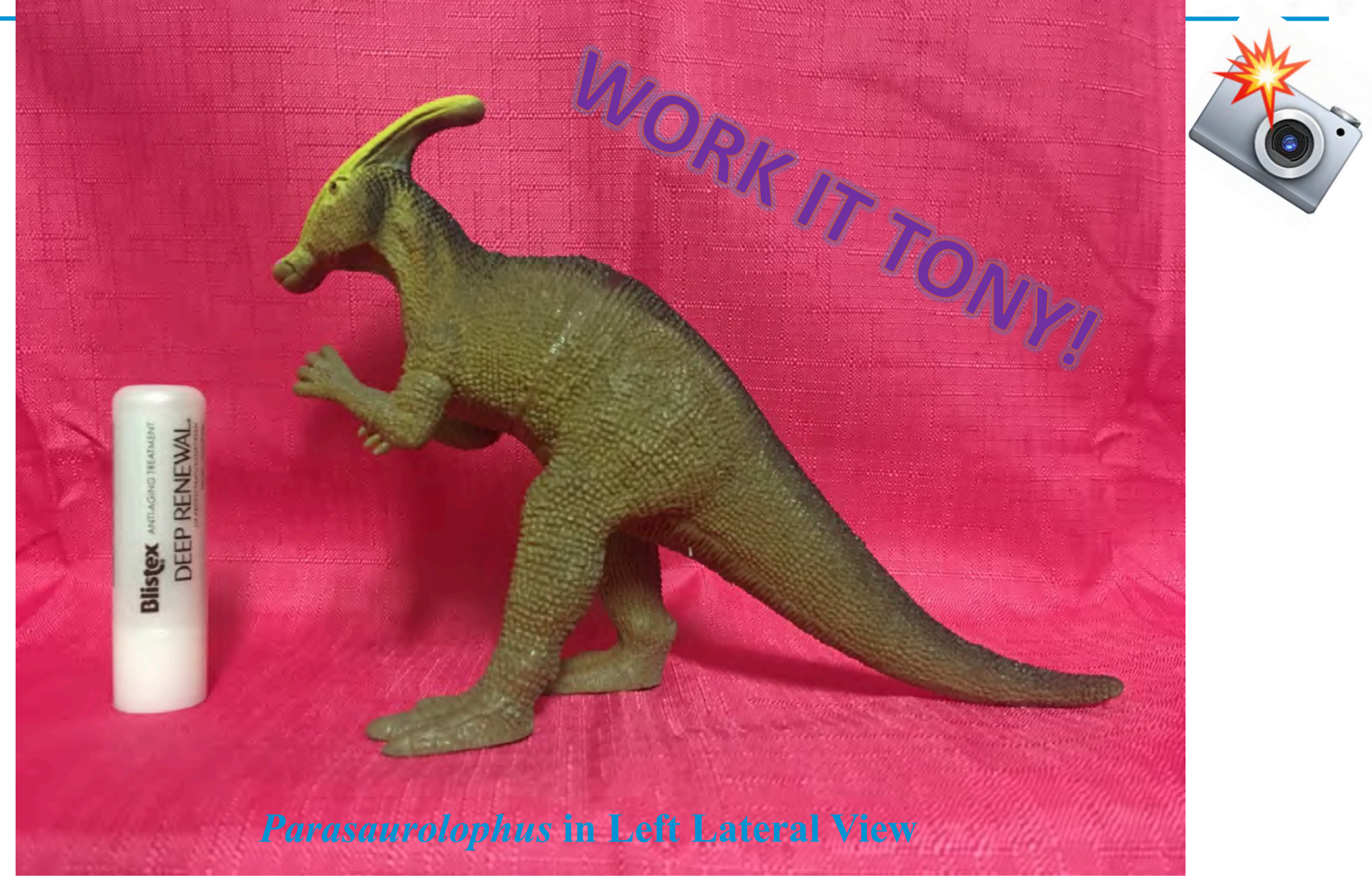

Student slides 


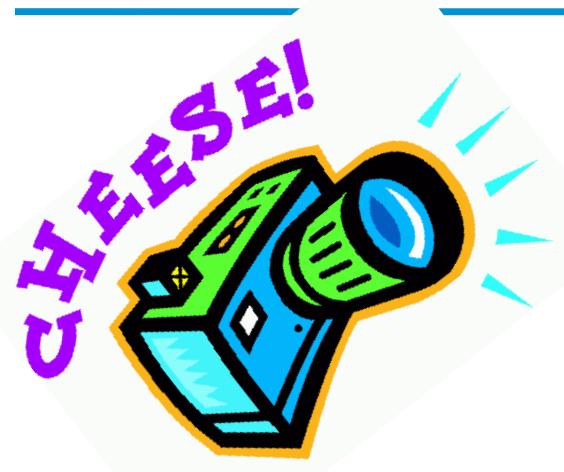

\section{WEEEEEERRRRKK!}

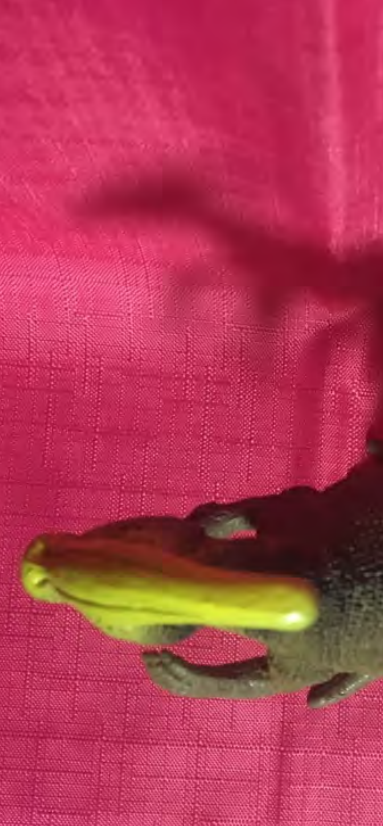


Parasaurlophus in Anterior View

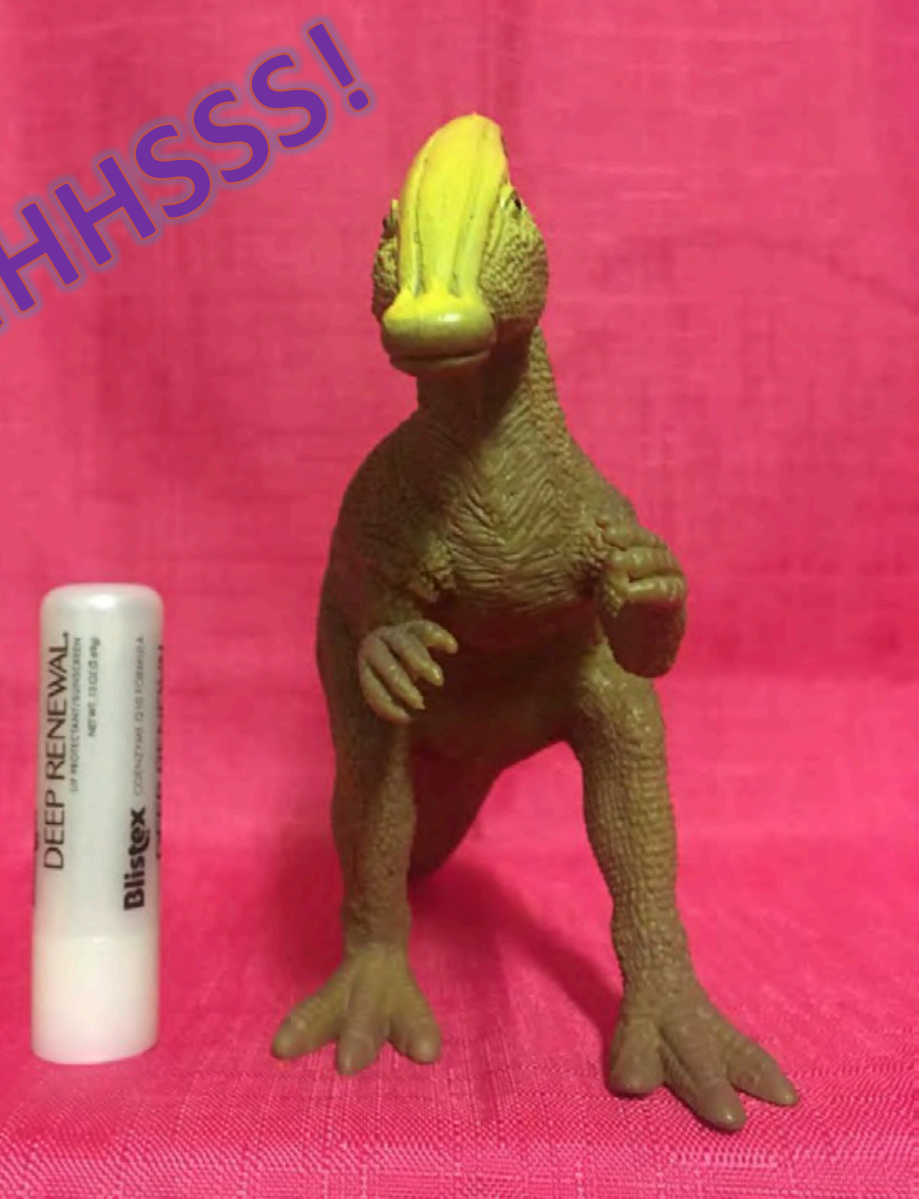

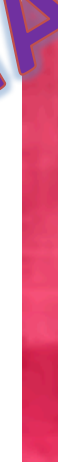

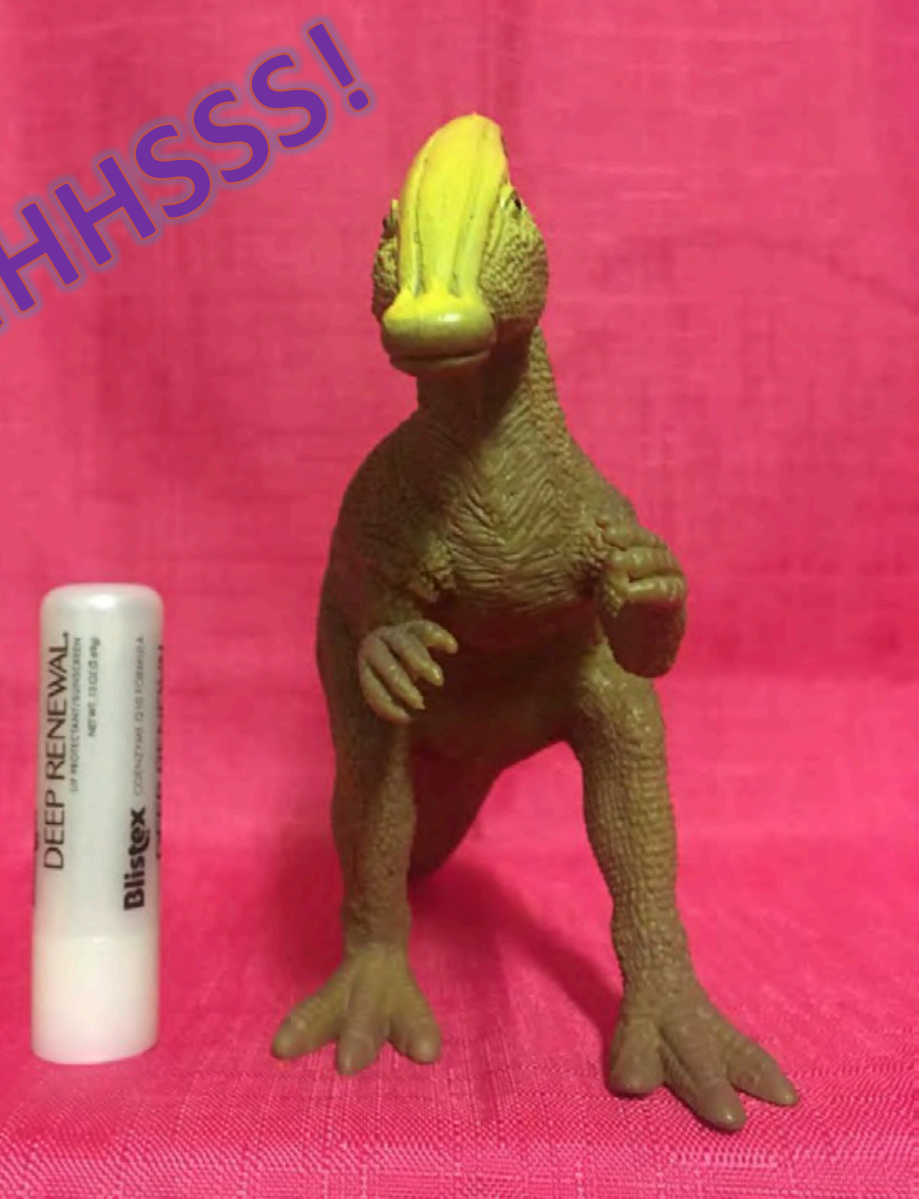

